\title{
MEASUREMENTS OF THE VENTILATION OF DWELLINGS
}

\author{
By C. G. WARNER, Рн.D., B.Sc. \\ Of the Industrial Health Research Board and the \\ London School of Hygiene and Tropical Medicine
}

(With 4 Figures in the Text)

\section{CONTENTS}

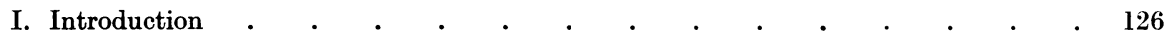

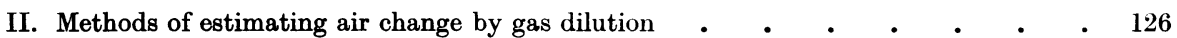

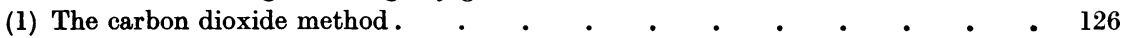

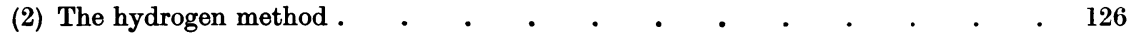

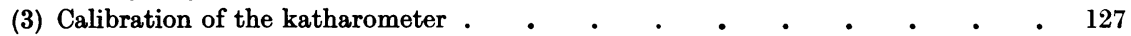

(a) Effect of atmospheric conditions on the katharometer . . . . . . 127

(4) Comparison of the katharometer with other methods of measuring air change $\quad$ - 128

(a) Katharometer and direct air-flow measurements . . . . . . . 128

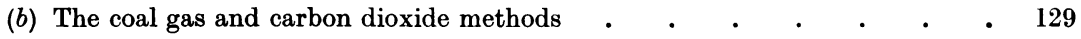

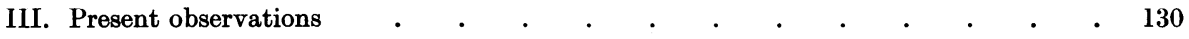

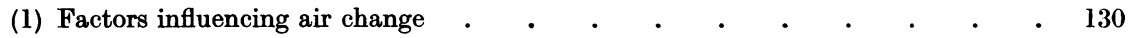

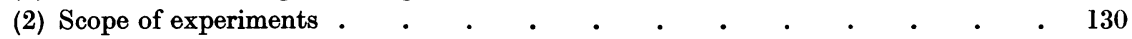

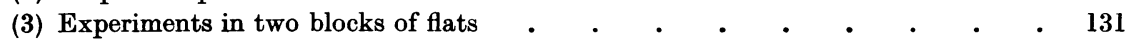

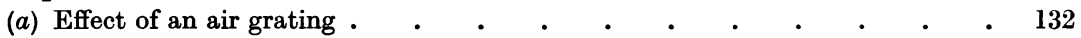

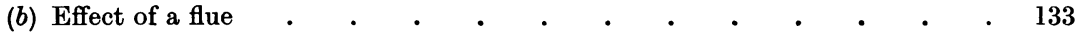

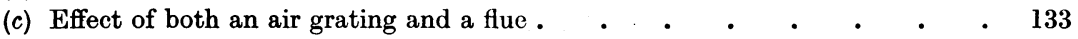

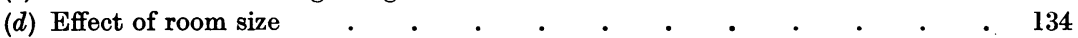

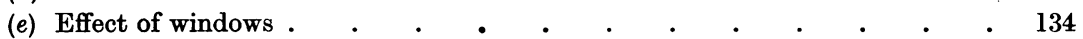

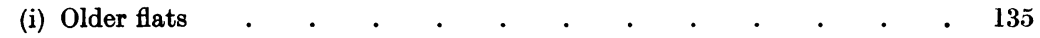

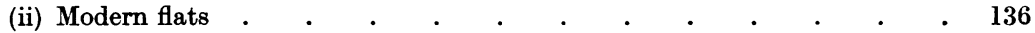

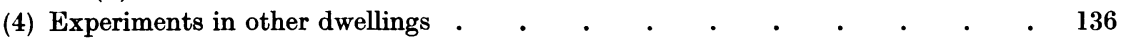

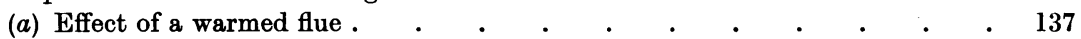

(5) Experiments in a university building • . . . . . . . . . . . $\quad$. 137

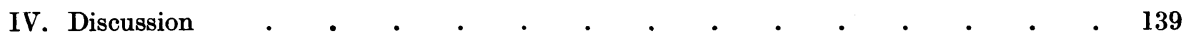

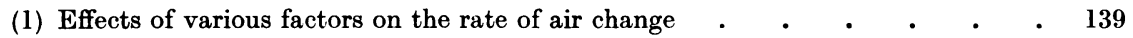

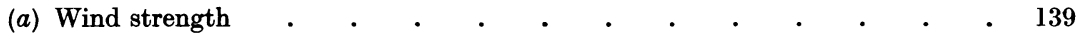

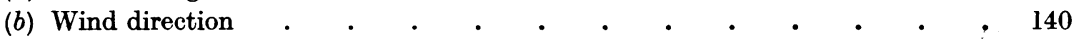

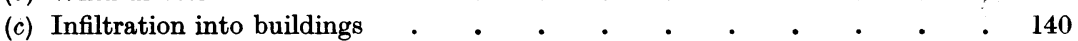

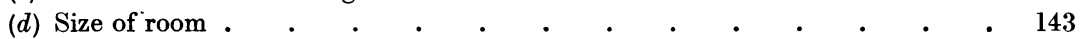

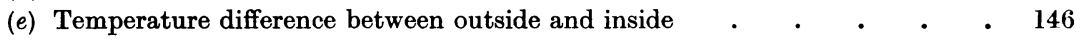

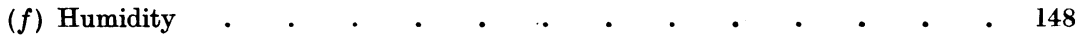

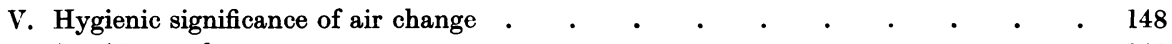

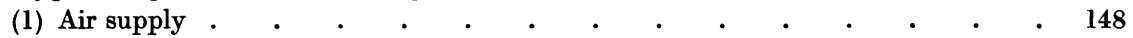

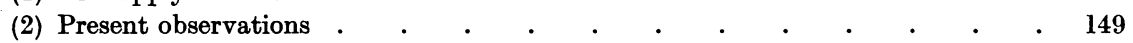

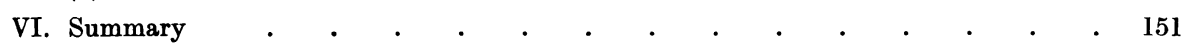

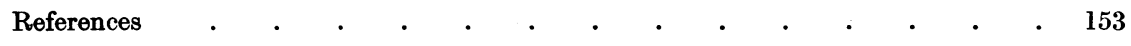

J. Hygiene 40 


\section{INTRODUCTION}

THE amount of ventilation obtained in small rooms, particularly of the size met with in dwelling houses, is a matter which has been discussed by hygienists for many years past, but in spite of this interest comparatively few measurements of the actual rate of ventilation have been made. An Advisory Committee appointed by the Royal College of Physicians in 1936 commented on the paucity of information available and expressed the opinion that more extended tests should be carried out, especially in regard to the minimum degree of ventilation in small flueless apartments typical of certain modern buildings. The investigation described in this paper was undertaken with the object of gaining information on the subject.

Where fixed mechanical systems of ventilation exist it is a simple matter to ascertain the quantity of air entering or leaving a room. Direct measurement can be made of the air being moved by fans, and from this the amount of outside air entering can be estimated. But with natural ventilation the task of assessing the rate of air change is one of greater difficulty.

If the room is ventilated at a constant rate the amount of original air in the room decreases exponentially, and the amount of any foreign gas suddenly introduced into the room decreases in like manner. When a volume of fresh air equal to $x$ times the volume of the room has been introduced, or, as it is commonly expressed, when $x$ air changes have taken place, the volume of original air remaining is equal to $e^{-x}(e=$ base of Naperian logarithms, $2 \cdot 718)$. Thus after one air change it can be calculated that there is still $36.8 \%$ of the original air remaining in the room.

\section{Methods of estimating aIR Change by Gas Dilution}

If a foreign gas is liberated into the room and its subsequent dilution traced by the examination of samples of the room air, the rate of air change can readily be calculated if the time interval between successive examinations is known. In the past, ventilation has commonly been measured by liberating carbon dioxide and ascertaining its rate of disappearance, but in recent years hydrogen has also been used for this purpose.

\section{(1) The carbon dioxide method}

Reliable results have been obtained by the use of carbon dioxide, but the taking of air samples and their subsequent analysis is a rather laborious process, especially if it is desirable to make successive determinations at frequent intervals.

\section{(2) The hydrogen method}

The rate of air change can be determined by the dilution method more easily if hydrogen is used as the foreign gas and its concentration measured by means of the katharometer (Marley, 1935). This instrument was devised 
by Shakespear and described by Daynes (1920). It consists essentially of a Wheatstone bridge circuit. Four identical spirals of platinum wire, one in each arm of the bridge, are heated by a constant electric current. Two spirals, in opposite arms of the bridge, are exposed to a standard gas-normal airtrapped in sealed cells, and the other two to the gas under test. The difference in the thermal conductivities of the standard gas and that under test canses the spirals to cool at different rates, and the resulting difference in the resistances of the spirals unbalances the bridge and a deflexion is obtained on a galvanometer.

The thermal conductivity method possesses a number of advantages. It enables minute changes in gas composition to be accurately measured; continuous direct readings; which do not involve intermittent withdrawals of samples of the air and their subsequent analysis, are obtained on the galvanometer; and the gas mixture is not altered in composition during the measurement. Hydrogen is the best gas to use as its thermal conductivity is about seven times that of air, and consequently traces of this gas in air can be estimated readily by means of the katharometer.

In field work the use of hydrogen would have entailed the transporting of heavy gas cylinders. This was a practical disadvantage and the use of ordinary coal gas, which contains about $50 \%$ of hydrogen, as the foreign gas, was tried. Laboratory experiments confirmed that the use of coal gas was practicable.

\section{(3) Calibration of the katharometer}

Preliminary experiments with the katharometer in a small, gastight, steel-walled chamber showed that there was a linear relationship between concentration of coal gas and galvanometer deflexion. The result of a typical experiment is plotted in Fig. 1. A concentration of $0.1 \%$ of coal gas gave about 15 divisions deflexion, representing a current through the galvanometer of $7 \cdot 5 \mu \mathrm{A}$.

In subsequent experiments it was found that a concentration of between 0.2 and $0.3 \%$ of coal gas at the beginning of an air-change determination was sufficient. This concentration is well below the lower explosive limit, and exposure to the consequent low concentration of carbon monoxide caused no harm to the observer.

(a) Effect of atmospheric conditions on the katharometer.

It was noticed that atmospheric humidity and temperature affected the katharometer and that the galvanometer reading in clean air varied from day to day. On the basis of experiments over a fairly wide range of temperature and humidity an empirical relation was established which enabled a satisfactory correction to be applied for any small change in humidity or temperature that might occur during an experiment. Subsequent experience showed that in 136 observations the galvanometer reading in clean air could be calculated with an average error of only about one scale division if the dry- and wet-bulb temperatures were known. 
(4) Comparison of the katharometer with other methods of measuring air change

Before field observations were begun the katharometer method was checked against other methods in the laboratory.

(a) Katharometer and direct air-flow measurements.

In one series of tests an ordinary gas meter and the katharometer were connected in series with a galvanized iron tank of 56 1. capacity. A small quantity of coal gas was released into the tank, and a steady stream of air

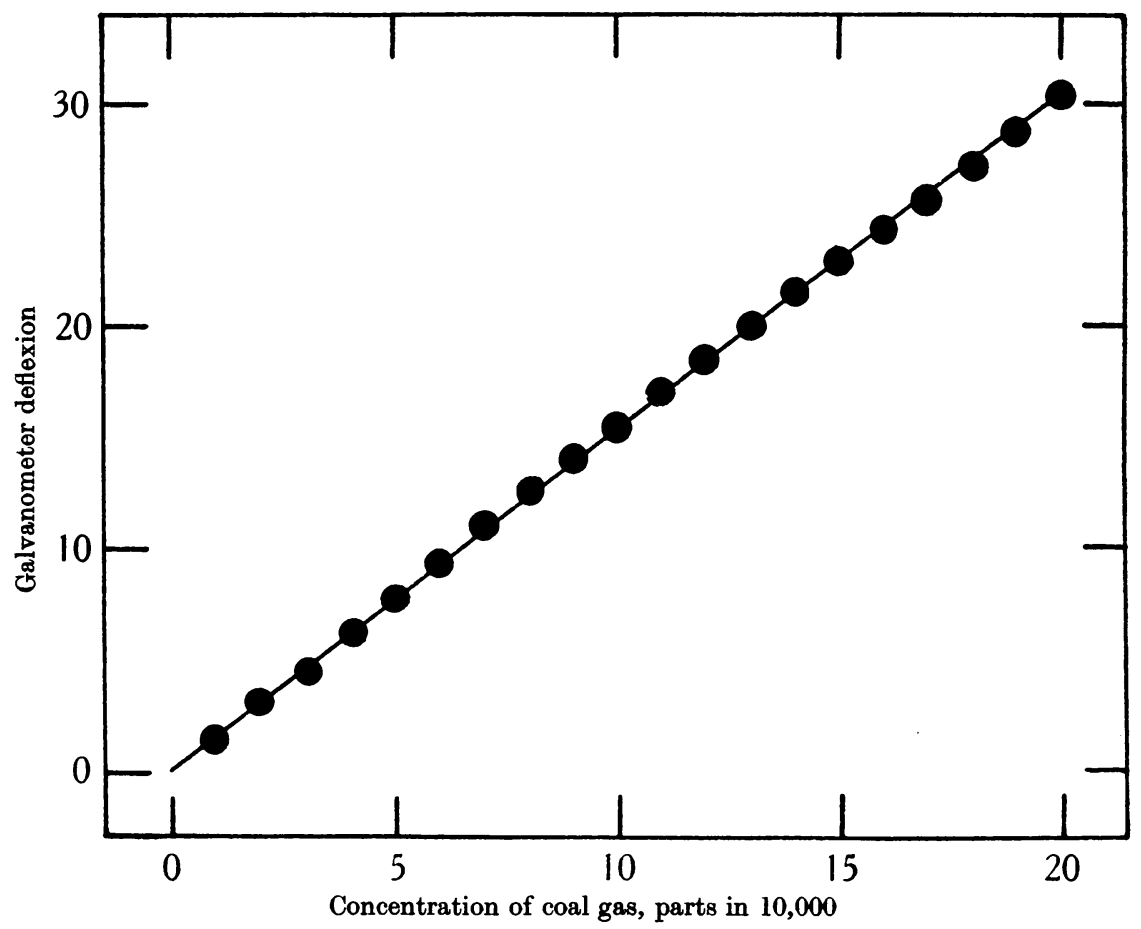

Fig. 1. Relation of gas concentration to galvanometer deflexion.

was then passed through the complete apparatus. Synchronous readings were taken on the gas meter and on the galvanometer, and the rate of air change within the tank thus assessed: (i) by direct measurement of the quantity of air passed, and (ii) by the katharometer method.

As is shown in Fig. 2, there was remarkably close agreement between the results given by the two methods with ventilation rates varying from 1 to 22 air changes per hour. In ten pairs of experiments the average ventilation rates by the two methods differed by only 0.06 air change per hour, or only $1.8 \%$, and the average of the individual differences between pairs of observations was only $4 \%$. 
Marley (1935) also obtained close agreement between air-change readings by the katharometer and direct measurements of air flow.

(b) The coal gas and carbon dioxide methods.

On four occasions consecutive pairs of experiments were made in closed rooms in which the air change was determined (i) by the katharometer method, using coal gas, and (ii) by the Haldane gas analysis technique, using carbon dioxide.

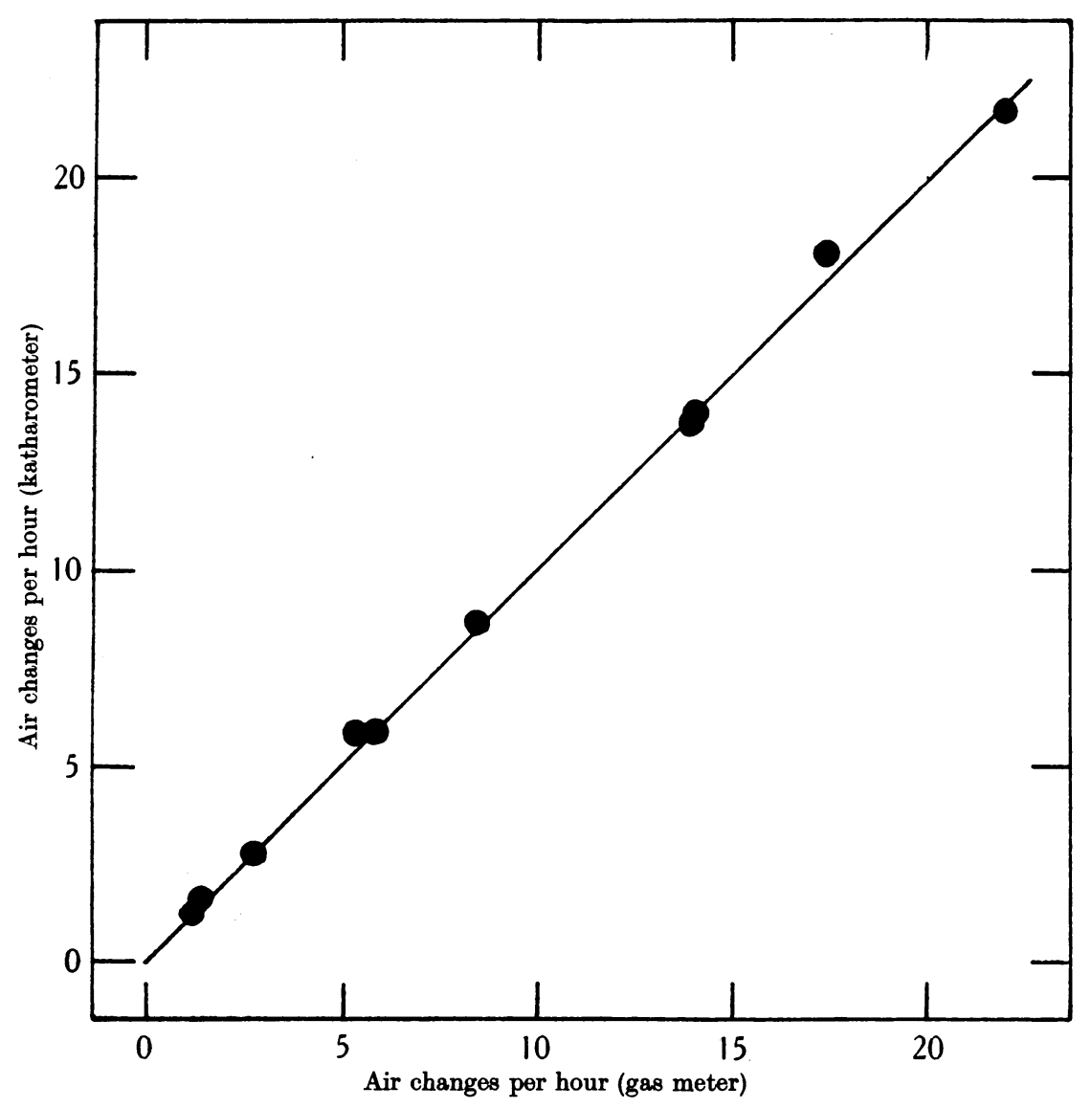

Fig. 2. Comparative measurements of air change in small test chamber, using (a) katharometer, (b) gas meter.

In these tests the observer was outside the room, the samples for analysis being withdrawn by means of a small-bore rubber tube passing through the keyhole. The results given by the katharometer and carbon dioxide methods respectively in different pairs of experiments were 0.22 and $0 \cdot 27,0 \cdot 15$ and $0 \cdot 17$, 0.15 and 0.12 , and 0.47 and 0.48 air change per hour, these values being virtually identical. 


\section{Present observations}

\section{(1) Factors influencing air change}

The following conditions must be fulfilled if any enclosure is to be ventilated:

(i) There must be openings or pores in the structure of the building fabric which will permit the air to flow in and out.

(ii) Such forces must exist as will cause air to flow through these openings.

The factors under these two headings which appear likely to influence air change are:

(i) (a) The opening of doors and windows.

(b) Effect of fixed ventilators (air gratings, flues, etc.).

(c) Cracks in the structure and finishing surfaces of the rooms and the chinks or other apertures which to a greater or lesser extent exist round windows and doors.

(d) Porosity of structural materials, including the effects of the internal decoration of the walls.

(ii) (a) Strength and direction of the wind.

(b) Temperature difference between room air and external air.

(c) Temperature in flues.

(d) Difference in humidity between room air and external air.

(e) Height of room above ground-level.

$(f)$ Changes in barometric pressure. In air-change determinations of short duration the effect of this factor may be excluded.

Many of these factors are likely to act simultaneously, so that it becomes a difficult matter to estimate the effects of each separately.

\section{(2) Scope of experiments}

In all, 312 experiments on the rate of air change with the hydrogen method were made in thirty-one different rooms. The distribution of these observations was as follows (dates of construction are shown in brackets):

$\begin{array}{cc}\begin{array}{c}\text { No. of } \\ \text { rooms tested }\end{array} & \begin{array}{c}\text { No. of } \\ \text { experiments }\end{array} \\ 9 & 95 \\ 4 & 66 \\ 5 & 66 \\ 4 & 32 \\ 3 & 24 \\ 6 & 29\end{array}$

Building and date

Block A, of modern flats (1936)

Block B, of older flats (1888)

House C, detached villa-residence (1928)

House D, semi-detached villa-residence (1913)

House E, semi-detached villa-residence (1898)

Building F, modern university building (1928)

Dry- and wet-bulb temperature readings were taken in conjunction with the katharometer observations. The meteorological conditions outside were also determined. The speed and direction of the wind were noted, together with dry- and wet-bulb temperatures. The air velocity was measured by means of a silvered kata-thermometer. These outside readings were always taken alongside the external wall (or walls) of the room under test. While 
the air velocity thus measured is indicative of the wind effect on the windows and external wall it does not necessarily indicate the strength of the wind passing over the chimney.

\section{(3) Experiments in two blocks of flats}

The experiments in the two blocks of flats will be described first. Block A was a modern ferro-concrete structure, with steel-framed windows, whilst block B was of older construction, with cavity walls of brick and wooden sash windows.

The two blocks were in the same neighbourhood, with similar orientation. So far as possible, rooms with the same aspect in the two blocks were chosen for the tests. Thus it was hoped that in comparing the rates of air change in the old and modern dwellings the effects of some of the extraneous climatic factors affecting natural ventilation would cancel out.

The rooms selected in the two blocks of flats can be classified as follows:

$\begin{array}{ll}\text { Block A (modern flats): } & \\ \text { Flueless rooms, each with } & \text { Nos. } 1,2,3,4 \\ \quad \text { one air grating } & \\ \begin{array}{c}\text { Rooms with flue, but no } \\ \text { air grating }\end{array} & \text { Nos. } 5,6,7,8,9 \\ \text { Block B (older flats): } & \\ \text { Rooms with fireplace flue } & \text { Nos. } 10 \text { and } 12 \\ \quad \begin{array}{l}\text { and one air grating } \\ \text { Rooms with fireplace flue } \\ \text { only }\end{array} & \text { Nos. } 11 \text { and } 13\end{array}$

The flueless rooms in block A (rooms 1-4) were each provided with one louvred-type air grating, of which the effective opening area was 10.5 sq. in.

Rooms 6-9 in the modern flats provided with flues were fitted with wallpanel gas fires. These were connected, not to flues of the size commonly used with open fires, but to flue pipes of 4 in. diameter, giving in each case a cross-sectional area of $12 \cdot 6 \mathrm{sq}$. in.

The rooms in the older flats, block $B$, were each provided with both an ordinary fireplace flue and one air grating. The effective opening area of the lattice-work type of metal grating used was $6 \mathrm{sq}$. in. In all the rooms the fireplaces were similar, and the cross-sectional area of the register opening was constant at $53 \mathrm{sq}$. in. In both blocks of flats the air gratings were of fixed types and had no movable baffles; they were also completely free from external obstructions, such as ivy. The gratings were built into the walls of the rooms at a height of $7 \mathrm{ft} .6$ in. above floor-level.

The experiments to be described were performed during the spring and winter seasons. The outside wind speed varied from 0.50 to 6.87 m.p.h. and the outside dry-bulb temperature from $37 \cdot 0$ to $78 \cdot 4^{\circ} \mathrm{F}$. Distributions of these 
two factors for the 69 days of observation are shown in Table 1. The ranges of wind speed taken are those corresponding to numbers 0,1 and 2 on the Beaufort Scale. Throughout this part of the investigation the small amount of variation in wind speed was particularly noticeable. On 4 days only did the velocity exceed 4 m.p.h. at working level. But in a densely built area this is not surprising, as buildings shield each other and break down the force of the wind. In experiments made throughout a whole year in an urban area Wellner (1932) observed average wind speeds of $2 \cdot 31$ m.p.h. during winter, $2 \cdot 16$ m.p.h. during summer, and 1.64 m.p.h. in other seasons. These figures agree closely with those obtained during the present inquiry.

\section{Table 1. Frequency of occurrence of outside weather conditions}

$\begin{array}{cc}\text { Dry-bulb temperature } \\ \begin{array}{c}\text { No. of days } \\ \text { at which } \\ \text { temperature } \\ \text { wange, }\end{array} \\ \begin{array}{c}\text { was observed } \\ \text { Under } 40\end{array} \\ 40-50 & 6 \\ 50-60 & 19 \\ 60-70 & 12 \\ 70 \text { and over } & 29\end{array}$

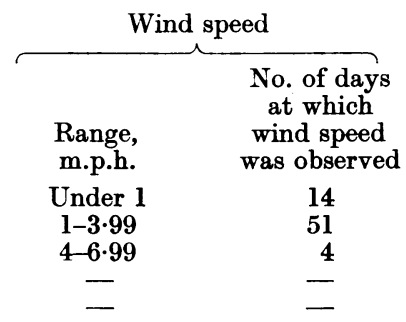

In all the experiments one person (the observer) was present in the room during the air-change determination, and no artificial heating was used at any time.

\section{(a) Effect of an air grating.}

In Table $2^{1}$ are given the results of experiments showing the effect of an air grating on the rate of air change in the two blocks of flats. In all cases doors and windows were kept closed, but no attempt was made to block up any cracks around them. Conditions therefore were those which would prevail with the normal closure of doors and windows. In the older flats, which had both a flue and an air grating, the fireplaces were carefully sealed for this series of tests.

Table 2. Effect of an air grating on the rate of air change

\begin{tabular}{|c|c|c|c|c|c|c|}
\hline \multirow[b]{2}{*}{$\begin{array}{l}\text { Type } \\
\text { of flat }\end{array}$} & \multirow{2}{*}{ Room no. } & \multicolumn{2}{|c|}{ Air grating open } & \multicolumn{2}{|c|}{ Air grating closed } & \multirow[b]{2}{*}{$\begin{array}{c}\text { Mean } \\
\text { outside } \\
\text { wind } \\
\text { speed, } \\
\text { m.p.h. }\end{array}$} \\
\hline & & $\begin{array}{c}\text { Mean no. of } \\
\text { air changes } \\
\text { per hr. }\end{array}$ & $\begin{array}{l}\text { Vol. of air } \\
\text { entering } \\
\text { room, } \\
\text { cu. ft. }\end{array}$ & $\begin{array}{c}\text { Mean no. of } \\
\text { air changes } \\
\text { per hr. }\end{array}$ & $\begin{array}{l}\text { Vol. of air } \\
\text { entering } \\
\text { room, } \\
\text { cu. ft. }\end{array}$ & \\
\hline $\begin{array}{l}\text { Block A } \\
\text { (modern) }\end{array}$ & $1,2,3,4$ & 0.83 & 580 & 0.55 (17) & 386 & 1.44 \\
\hline $\begin{array}{c}\text { Block B } \\
\text { (older) }\end{array}$ & 10,12 & $1.04(10)$ & 1208 & 0.71 (12) & 829 & 1.77 \\
\hline
\end{tabular}

1 The figures in brackets in this and subsequent tables refer to the numbers of experiments on which the mean results are based. 
With air gratings closed the rates of air change in the modern and older flats were 0.55 and 0.71 per hour respectively. The modern concrete-built flats would be expected to be more impermeable to air than the older ones.

The actual volumes of the rooms (allowance being made for contents) varied, in the modern flats from 535 to $810 \mathrm{cu}$. ft., and in the older ones from 900 to $1435 \mathrm{cu}$. $\mathrm{ft}$. Small rooms tend to have more air changes owing to the greater ratio of wall surface to room volume, but in spite of this the older rooms had the bigger air change. This is probably due to constructional differences, but it should be noted that the outside wind speed was slightly higher in the block B experiments.

With the air gratings open the air change increased to 0.83 per hour in the modern flats and to $1 \cdot 04$ per hour in the older flats.

When the comparison is confined to experiments where determinations with the air grating open and closed were done consecutively (seventeen pairs of experiments in the modern flats and eight pairs in the older flats) the mean results are almost identical with those already quoted in Table 2.

\section{(b) Effect of a flue.}

Attention must be drawn to the difference in size of the flue openings in the two blocks of flats. The larger rooms in the modern flats were fitted with a small wall-panel gas fire, which was connected to a flue pipe of $4 \mathrm{in}$. diameter, giving an effective area of $12.6 \mathrm{sq}$. in. In the older flats the rooms had ordinary fireplaces and the effective area of the register opening was $53 \mathrm{sq}$. in. In this series of experiments air gratings in the older flats were sealed off, and doors and windows kept closed. Table 3 shows the results obtained.

Table 3. Effect of a flue on the rate of air change

\begin{tabular}{|c|c|c|c|c|c|c|c|}
\hline & & Flue & & Flue $\mathrm{c}$ & sed & & \\
\hline $\begin{array}{c}\text { Type } \\
\text { of room }\end{array}$ & Room no. & $\begin{array}{l}\text { Mean } \\
\text { no. of air } \\
\text { changes } \\
\text { per hr. }\end{array}$ & $\begin{array}{c}\text { Vol. } \\
\text { of air } \\
\text { entering } \\
\text { room, } \\
\text { cu. ft. } \\
\text { per hr. }\end{array}$ & $\begin{array}{l}\text { Mean } \\
\text { no. of air } \\
\text { changes } \\
\text { per hr. }\end{array}$ & 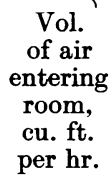 & $\begin{array}{c}\text { Mean } \\
\text { outside } \\
\text { wind } \\
\text { speed, } \\
\text { m.p.h. }\end{array}$ & $\begin{array}{l}\text { Mean } \\
\text { flue } \\
\text { area, } \\
\text { sq. in. }\end{array}$ \\
\hline $\begin{array}{l}\text { Block A } \\
\text { (modern) }\end{array}$ & $6,7,8,9$ & $1 \cdot 17(19)$ & 1078 & $0 \cdot 84(16)$ & 767 & $2 \cdot 75$ & $12 \cdot 6$ \\
\hline $\begin{array}{c}\text { Block B } \\
\text { (older) }\end{array}$ & $10,11,12,13$ & 2.06 & 2300 & $0.72(24)$ & 820 & $2 \cdot 15$ & $53 \cdot 0$ \\
\hline
\end{tabular}

The volumes of the rooms studied in these experiments varied in the modern flats from 865 to $938 \mathrm{cu}$. ft., and in the older flats from 900 to $1435 \mathrm{cu}$. ft.

The figures demonstrate the efficacy of a fireplace flue as a means of ventilation and show the desirability of a flue of adequate cross-sectional area.

(c) Effect of both an air grating and a flue.

In the older flats some experiments were made to test the effect of both an air grating and a fireplace flue on the rate of air change. The results are given in Table 4. 
Table 4. Effect of both an air grating and a flue on the rate of air change

Ventilation openings
None
Air grating only ( 6 sq. in.)
Flue only (53 sq. in.)
Air grating and flue

Mean no. of air
changes per hr.
$0 \cdot 76(7) \quad(=100)$
$1 \cdot 11 \quad(5) \quad(=146)$
$1.97(4) \quad(=259)$
$2 \cdot 34(4) \quad(=308)$

$\begin{array}{cc}\begin{array}{c}\text { Vol. of air } \\ \text { entering }\end{array} & \begin{array}{c}\text { Mean } \\ \text { outside } \\ \text { per hr., } \\ \text { wind speed, } \\ \text { cu. ft. }\end{array} \\ \text { m.p.h. } \\ 904 & 2 \cdot 20 \\ 1266 & 1 \cdot 80 \\ 2201 & 2 \cdot 38 \\ 2573 & 2 \cdot 18\end{array}$

The rate of air change was highest with both an air grating and flue open, due regard being paid to outside wind speed.

Taking the rate of natural ventilation when the rooms were entirely closed as a basis, opening the air grating increased the air change by about one-half. With only the flue open, the ventilation was some $2 \frac{1}{2}$ times the basic value, whilst with both the grating and flue open, the air change was increased to threefold.

(d) Effect of room size.

Reference has already been made to the variation in rate of air change likely to occur in different sized rooms. In the modern flats the room volumes varied but little: the sizes of the flueless rooms ranged from 535 to $810 \mathrm{cu}$. ft., and those of the gas-fire flue rooms from 865 to $938 \mathrm{cu}$. $\mathrm{ft}$. There was not enough variation in size in either of these groups to warrant further subdivision, but in the older flats the rooms were of two distinct sizes, rooms 10 and 11 averaging $918 \mathrm{cu}$. ft. and rooms 12 and 13 averaging $1433 \mathrm{cu}$. ft. in actual volume. The results of experiments in these four rooms have been divided according to room size and the averages are given in Table 5.

Table 5. Comparison of air change in rooms of varying size but of similar construction

\begin{tabular}{|c|c|c|c|c|c|c|}
\hline \multirow[b]{2}{*}{$\begin{array}{c}\text { Ventilation } \\
\text { openings }\end{array}$} & \multicolumn{3}{|c|}{ Rooms 10 and 11 (918 cu. ft.) } & \multicolumn{3}{|c|}{ Rooms 12 and 13 (1433 cu. ft.) } \\
\hline & $\begin{array}{c}\text { Mean no. } \\
\text { of air } \\
\text { changes } \\
\text { per hr. }\end{array}$ & $\begin{array}{l}\text { Vol. of air } \\
\text { entering } \\
\text { per hr., } \\
\text { cu. ft. }\end{array}$ & $\begin{array}{c}\text { Mean } \\
\text { outside } \\
\text { wind } \\
\text { speed, } \\
\text { m.p.h. }\end{array}$ & $\begin{array}{c}\text { Mean no. } \\
\text { of air } \\
\text { changes } \\
\text { per hr. }\end{array}$ & $\begin{array}{c}\text { Vol. of air } \\
\text { entering } \\
\text { per hr., } \\
\text { cu. ft. }\end{array}$ & $\begin{array}{c}\text { Mean } \\
\text { outside } \\
\text { wind } \\
\text { speed, } \\
\text { m.p.h. }\end{array}$ \\
\hline ne & $0 \cdot 87(11)$ & 799 & 1.99 & $0.58(13)$ & 837 & $2 \cdot 08$ \\
\hline Air grating only & $1.33 \quad(4)$ & 1193 & $1 \cdot 79$ & $0.86 \quad(6)$ & 1218 & 1.52 \\
\hline Flue only & $2.44(12)$ & 2256 & $2 \cdot 29$ & 1.64 (11) & 2349 & $2 \cdot 31$ \\
\hline Air grating and flue & $2 \cdot 89 \quad(2)$ & 2601 & $2 \cdot 20$ & $1.79 \quad(2)$ & 2546 & $2 \cdot 17$ \\
\hline
\end{tabular}

For each condition of ventilation the rate of air change in the smaller rooms is the higher.

So far, outside wind speed is the only climatic factor against which the results have been classified. Other variables will probably have played their part, and the effect of some of these is discussed in a later section.

(e) Effect of windows.

The experiments already described were performed with doors and windows normally closed and fastened. It is obvious that by opening these ventilators 
almost any degree of air change could be obtained. It was thought to be of interest, however, to study the effect on the rate of air change with various openings of windows. Table 6 gives details of these experiments in both blocks of flats. ("Hopper" window is used as an alternative name for "tophung" casement.)

Table 6. Experiments with various openings of windows

Room no.

Conditions of windows opened

Modern flats

Flueless rooms (air grating open)

2

3

Hopper full open
Casement open to $\frac{3}{8}$ in.

Casement full open

Hopper half open

Hopper full open

Casement open to $\frac{1}{4}$ in.

Hopper full open

Hopper full open

Casement open to 6 in.

Hopper full open

4

Casement full open

Hopper full open

Hopper full open

2 casements open to $\frac{8}{8}$ in.

Rooms with flues (flues open)
6

8

9

$\begin{array}{cc}\begin{array}{c}\text { Mean no. } \\ \text { of air }\end{array} & \begin{array}{c}\text { Mean } \\ \text { outside } \\ \text { changes }\end{array} \\ \text { wer hr. } & \text { m.p.h. }\end{array}$

$1 \cdot 01$

$0.94 \quad 1 \cdot 19$

$6.32 \quad 0.96$

$1 \cdot 09 \quad 0.84$

$1.17 \quad 0.84$

$2.64 \quad 1.98$

$\begin{array}{ll}1.87 & 1.98\end{array}$

$\begin{array}{ll}3.92 & 1.98\end{array}$

$5 \cdot 37 \quad 1.98$

$1.14 \quad 1.85$

$1.34 \quad 0.50$

$\begin{array}{ll}1.73 & 0.50\end{array}$

$\begin{array}{ll}1 \cdot 80 & 1 \cdot 71 \\ 2.06 & 1 \cdot 71 \\ 2.08 & 2 \cdot 53 \\ 1.69 & 2 \cdot 53 \\ 5.89 & 2 \cdot 53 \\ 3.65 & 4.99 \\ 0.89 & 4.99\end{array}$

10 has both a flue and an air grating, 11 and 13 have flue only

10

11

13
Older flats

\section{Hopper full open \\ 2 hoppers full open \\ 2 casements open to 1 in. \\ Hopper full open \\ Casement open to 6 in.) \\ 2 hoppers full ope}

Sash window open to 2 in.

Flue and air grating closed

Sash window open to 2 in.

Flue open: air grating closed

Sash window open to 2 in.)

Flue closed

Sash window open to 2 in.)

Flue open

Sash window open to 2 in.

Flue open
$1 \cdot 82$

1.47

$5 \cdot 40$

$1 \cdot 47$

1.95

$2 \cdot 03$

$4 \cdot 31$

$2 \cdot 03$

$8 \cdot 01$

$3 \cdot 73$

A few results are worthy of mention.

(i) Older flats. In room 10 the following rates of air change were found on the same morning:

Ventilation openings

Flue closed; air grating closed

Flue closed; air grating closed; top sash window open to a depth of 2 in.

Flue open; air grating closed; top sash window open to a depth of 2 in.

Mean outside wind speed, m.p.h.

\begin{tabular}{|c|c|}
\hline $\begin{array}{l}\text { Mean no. of } \\
\text { air changes } \\
\text { per hr. }\end{array}$ & $\begin{array}{l}\text { Vol. of air } \\
\text { entering per hr., } \\
\text { cu. ft. }\end{array}$ \\
\hline $\begin{array}{l}0.88 \\
1.82\end{array}$ & $\begin{array}{r}792 \\
1638\end{array}$ \\
\hline $5 \cdot 40$ & 4860 \\
\hline
\end{tabular}


The good effect of a fireplace flue is clearly shown. It was noticed on many occasions that such a flue exerted a good pull. Opening or shutting the flue increased or diminished the entry of air through cracks round doors, etc., immediately.

The observations in room 11 (Table 6) gave similar results.

(ii) Modern flats. In block $\mathrm{A}$ the windows were steel-framed, and the opening sections consisted of both side-hung and top-hung casements. The average opening area of a side-hung casement window was $5.5 \mathrm{sq}$. $\mathrm{ft}$. and of a top-hung casement (or hopper) window 1.33 sq. ft. The handle catches of the side-hung casements had notches by which the windows could be held open to the extent of only $\frac{1}{4}-\frac{3}{8}$ in. This is a common method of opening these windows, as it prevents an undue draught, and some experiments were therefore made with the windows in this position.

Taking the three flueless rooms, rooms $2-4$, the variations in the rate of air change shown in Table 7 were noted with different openings of windows.

Table 7. Variation in rate of air change in flueless rooms with various amounts of window opening (all experiments with air grating open)

$\begin{array}{lccc}\text { Ventilation openings } & \begin{array}{c}\text { Mean no. of } \\ \text { air changes } \\ \text { per hr. }\end{array} & \begin{array}{c}\text { Vol. of air } \\ \text { entering } \\ \text { per hr., } \\ \text { cu. ft. }\end{array} & \begin{array}{c}\text { Mean } \\ \text { outside } \\ \text { wind speed, } \\ \text { m.p.h. }\end{array} \\ \text { 1 top-hung casement (hopper) half open } & 1 \cdot 09(1) & 628 & 0.84 \\ \text { l top-hung casement (hopper) full open } & 1 \cdot 31 \quad(5) & 779 & 1 \cdot 27 \\ \text { 1 side-hung casement open to s. } \text { in. } & 1 \cdot 79(2) & 1141 & 1.59 \\ \text { l side-hung casement full open } & 6 \cdot 32 \quad(1) & 3640 & 0.96 \\ \text { Air grating alone (all windows closed) } & 0 \cdot 83(22) & 579 & 1.44\end{array}$

The effect of opening one casement window to a width of $\frac{3}{8}$ in. is striking. It increased the rate of air change to more than twice that found when the room was closed.

\section{(4) Experiments in other dwellings}

Experiments on the rate of air change were also made in three houses, C, D and E, in a provincial town. C was built in 1928, D in 1913 and $\mathrm{E}$ in 1898. All three were built of brick, with cavity walls.

The mean values of the rates of air change obtained in these houses, under various conditions of ventilation, are given in Table 8 .

The efficacy of an adequate sized flue as a means of ventilation is apparent, for in the nine rooms so provided, the average air change with flues open was $119 \%$ above the value obtained with flues closed.

The rates of air change observed in room 25 appear high in comparison with results already given for other rooms with air gratings only. This room had a large bay window and had three external walls. Presumably the relatively high air changes were due to this construction. 
Table 8. Natural ventilation rates observed in three houses

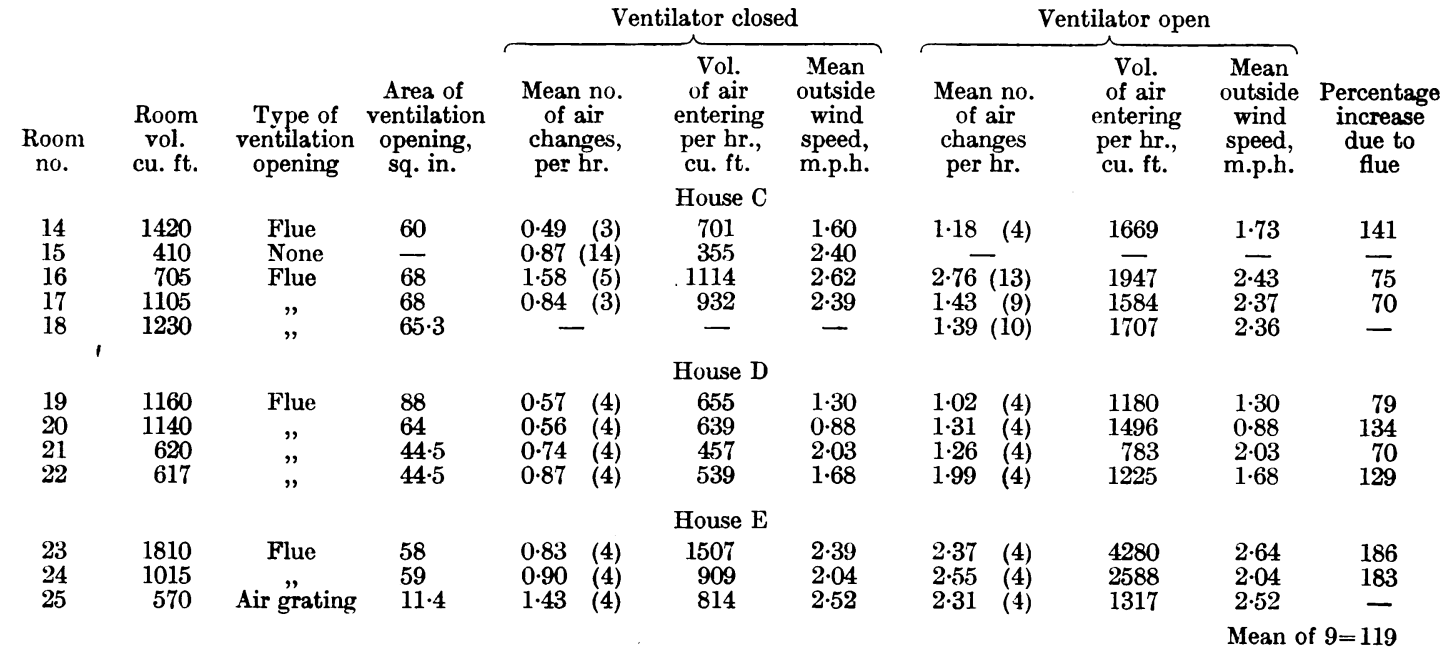

(a) Effect of a warmed flue.

In room 14 (a living room) the effect of a coal fire on the ventilation was studied. The results of a typical set of three experiments are shown in Fig. 3. The door and windows were normally closed and the beneficial effect of a warmed flue is shown. Taking the rate of air change with the flue closed as 100 , the rates with $(a)$ flue open (but no fire), and $(b)$ fire burning are respectively 272 and 755 . Haldane (1899) found that the air change of a room increased fivefold when a coal fire was alight.

One series of experiments in a bedroom, room 16, where a gas fire was fitted into the existing fireplace, gave the following results:

\begin{tabular}{lc} 
& $\begin{array}{c}\text { Mean no. of air } \\
\text { changes per } \mathrm{hr} . \\
\text { Flue closed }\end{array}$ \\
Flue open & $\begin{array}{l}1 \cdot 58=100 \\
\text { Gas fire burning }\end{array}$ \\
\hline
\end{tabular}

Further discussion on the data given in Table 8 appears in the next section.

\section{(5) Experiments in a university building}

The university building $(\mathrm{F})$ in which a number of tests were made was a modern structure some ten years old. It was solidly built, large parts of it being stone-faced; the walls and ceilings of the rooms were finished with a hard gypsum plaster and the floors were either parquet blocks or linoleum over concrete. The windows were steel-framed. For seven experiments in four rooms, with doors and windows closed, the rate of air change varied from $0 \cdot 13$ to 0.62 per hour. Bearing in mind the impermeable nature of the building the lowest values obtained were not surprising, although the rooms examined 
(their volumes ranged from 1080 to $5000 \mathrm{cu}$. ft.) were somewhat larger than those previously met with in flats and houses.

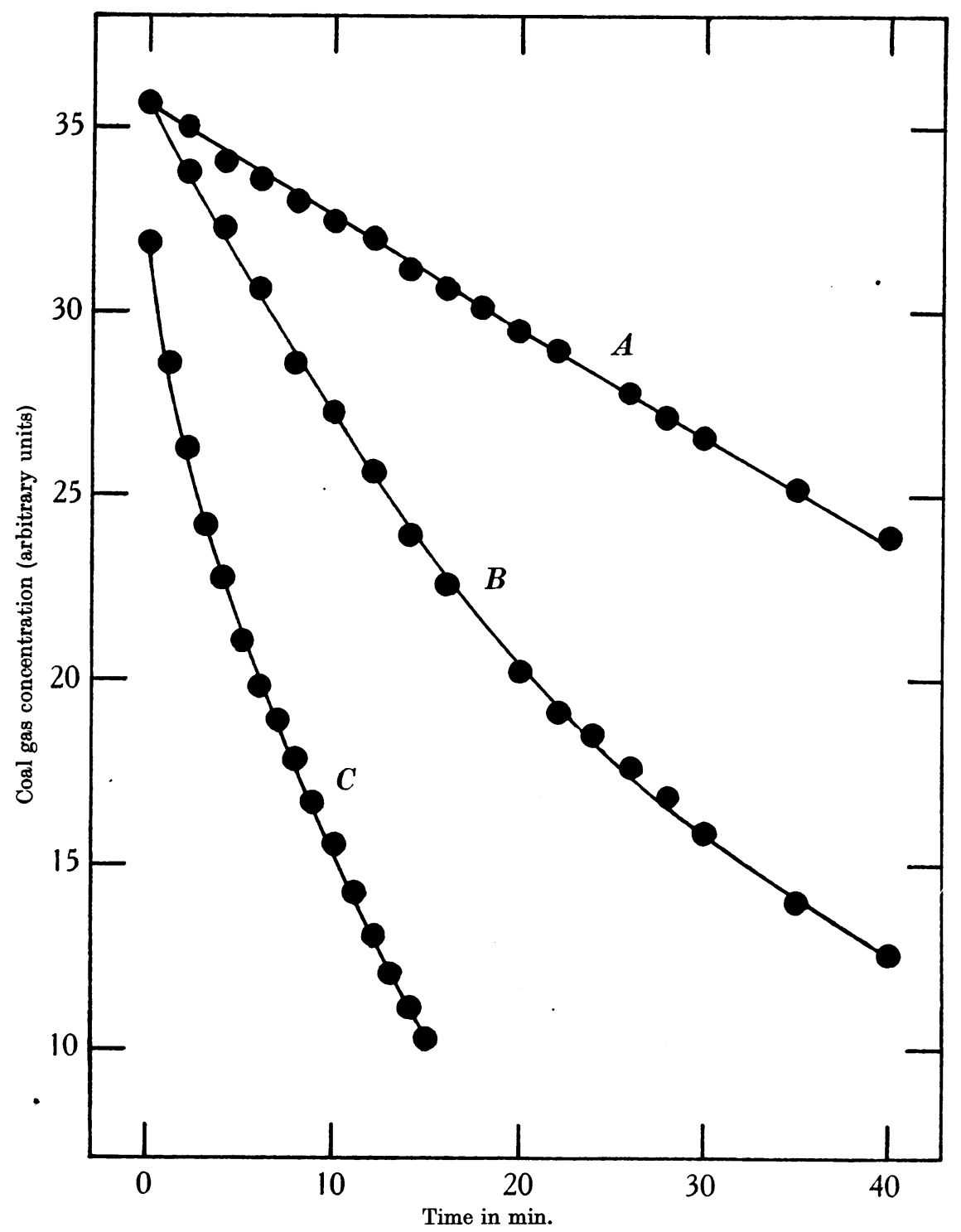

Fig. 3. Effect of a flue on ventilation of living room.

Curve $A$. Windows and door closed; flue sealed; $0 \cdot 6$ air change per hour.

Curve $B$. Windows and door closed; flue open; $1 \cdot 6$ air changes per hour.

Curve $C$. Windows and door closed; coal fire alight; 4.5 air changes per hour.

Determinations of air change were also made with various openings of windows. The results obtained with a narrow opening of side-hung casements will be dealt with in the section on leakage through steel-framed windows. When 
good cross-ventilation was effected, rates of air change as high as $31 \cdot 6$ per hour were noted. Individual results are given in Table 9 .

Table 9. Experiments in rooms in building $F$

\begin{tabular}{|c|c|c|c|c|}
\hline $\begin{array}{l}\text { Room } \\
\text { no. }\end{array}$ & $\begin{array}{l}\text { Actual } \\
\text { volume } \\
\text { of room, } \\
\text { cu. ft. }\end{array}$ & Conditions of ventilation & $\begin{array}{l}\text { Mean no. } \\
\text { of air } \\
\text { changes } \\
\text { per hr. }\end{array}$ & $\begin{array}{l}\text { Vol. of air } \\
\text { entering } \\
\text { per } \mathrm{hr} \text {., } \\
\text { cu. ft. }\end{array}$ \\
\hline \multirow[t]{7}{*}{26} & \multirow[t]{7}{*}{4800} & Windows and door closed & $0 \cdot 31$ & 1,489 \\
\hline & & , & $0 \cdot 17$ & 816 \\
\hline & & & $0 \cdot 36$ & 1,729 \\
\hline & & 3 windows partly open & $12 \cdot 2$ & $\tilde{58,584}$ \\
\hline & & , & $14 \cdot 6$ & 70,109 \\
\hline & & & $14 \cdot 3$ & 68,669 \\
\hline & & $\begin{array}{l}\text { Swivel over door"also open with above three } \\
\text { windows (cross-ventilation) }\end{array}$ & $22 \cdot 0$ & 105,644 \\
\hline 27 & 1690 & Windows and door closed & 0.62 & 1,049 \\
\hline \multirow{4}{*}{28} & \multirow{4}{*}{5070} & & $0 \cdot \overline{5} 3$ & 897 \\
\hline & & ", & $0 \cdot 13$ & 659 \\
\hline & & 4 casements open to $\frac{1}{4}$ in. & $1 \cdot 35$ & 6,845 \\
\hline & & $\begin{array}{l}\text { Swivel over door open as well as } 4 \text { casements } \\
\text { to } \frac{1}{4} \text { in. }\end{array}$ & 1.84 & 9,329 \\
\hline \multirow[t]{4}{*}{29} & \multirow[t]{4}{*}{1080} & $\begin{array}{l}\text { Windows and door closed } \\
2 \text { casements open to } \frac{1}{4} \text { in. }\end{array}$ & $\begin{array}{l}0 \cdot 35 \\
1 \cdot 80\end{array}$ & $\begin{array}{r}378 \\
1,944\end{array}$ \\
\hline & & & 1.29 & 1,393 \\
\hline & & $\begin{array}{l}\text { Swivel over door open as well as } 2 \text { casements } \\
\text { to } \frac{1}{4} \text { in. }\end{array}$ & $4 \cdot 28$ & 4,622 \\
\hline & & $\begin{array}{l}\text { As above, with swivel window open-brisk } \\
\text { cross-ventilation }\end{array}$ & $31 \cdot 64$ & 34,171 \\
\hline
\end{tabular}

\section{Discussion}

(1) Effects of various factors on the rate of air change

(a) Wind strength.

The effect of wind speed on the ventilation of a building is considerable. However well constructed a building may be there are always cracks and joints in the fabric through which air can pass. Haldane (1899) showed very distinctly the influence of wind in promoting air change in a closed room. With no ventilation in the room the rates of air change were found to be 0.43 per hour with "a scarcely perceptible breeze" and 0.78 per hour with "a strong wind". Thus on a windy day the ventilation was nearly double that on a still day. Later authors (e.g. Kisskalt (1913) and Wellner (1932)) have also demonstrated the effects of wind speed.

In the present observations also the effect of wind speed is shown. In Table 10 the experiments in the two blocks of flats are summarized in relation to this factor.

With the ventilator, air grating or flue, open, an increase in wind speed was associated with an increase in rate of air change in all rooms in both blocks. In the rooms provided with air gratings there was a similar relation when the gratings were closed.

In the rooms with flues, however, there was no consistent variation of ventilation with wind speed when the flues were closed. This may possibly be due to the small numbers of experiments included in some of the groups; 
for, as other workers have previously remarked, on occasions it is noticed that the rate of air change observed appears out of all proportion to the expected value with the conditions ruling at the time. Masterman, Dunning \& Densham (1935) reported that in individual tests by the same observer one result was double that in another similar experiment, for no apparent reason.

Table 10. Effect of outside wind speed on the rate of air change

\begin{tabular}{|c|c|c|c|c|c|}
\hline \multirow[b]{3}{*}{$\begin{array}{l}\text { Wind } \\
\text { strength, } \\
\text { Beaufort } \\
\text { scale }\end{array}$} & \multirow[b]{3}{*}{$\begin{array}{l}\text { Range } \\
\text { of wind } \\
\text { speed, } \\
\text { m.p.h. }\end{array}$} & \multicolumn{4}{|c|}{ Rooms with an air grating } \\
\hline & & \multicolumn{2}{|c|}{ Air grating open } & \multicolumn{2}{|c|}{ Air grating closed } \\
\hline & & $\begin{array}{l}\text { Mean no. of } \\
\text { air changes } \\
\text { per hr. }\end{array}$ & $\begin{array}{c}\text { Mean } \\
\text { outside } \\
\text { wind speed, } \\
\text { m.p.h. }\end{array}$ & $\begin{array}{l}\text { Mean no. of } \\
\text { air changes } \\
\text { per hr. }\end{array}$ & $\begin{array}{c}\text { Mean } \\
\text { outside } \\
\text { wind speed, } \\
\text { m.p.h. }\end{array}$ \\
\hline \multicolumn{6}{|c|}{ Block A (modern flats) } \\
\hline $\begin{array}{l}0 \\
1\end{array}$ & $\begin{array}{l}\text { Under } 1 \\
1-3.99\end{array}$ & $\begin{array}{l}0.73(7)=100 \\
0.88 \quad(15)=121\end{array}$ & $\begin{array}{l}0.75 \\
1 \cdot 70\end{array}$ & $\begin{array}{l}0.47(5)=100 \\
0.58(12)=123\end{array}$ & $\begin{array}{l}0 \cdot 78 \\
1 \cdot 78\end{array}$ \\
\hline \multicolumn{6}{|c|}{ Block B (older flats) } \\
\hline \multirow[t]{3}{*}{$\begin{array}{l}0 \\
1\end{array}$} & $\begin{array}{l}\text { Under } 1 \\
1-3 \cdot 99\end{array}$ & $\begin{array}{ll}0 \cdot 89 & (3)=100 \\
1 \cdot 10 & (7)=124\end{array}$ & $\begin{array}{l}0 \cdot 77 \\
1 \cdot 89\end{array}$ & $\begin{array}{ll}0 \cdot 44 & (2)=100 \\
0 \cdot 73 & (8)=166\end{array}$ & $\begin{array}{l}0.76 \\
1.97\end{array}$ \\
\hline & & \multicolumn{4}{|c|}{ Rooms with flue } \\
\hline & & \multicolumn{2}{|c|}{ Flue open } & \multicolumn{2}{|c|}{ Flue closed } \\
\hline $\begin{array}{l}\text { Wind } \\
\text { strength, } \\
\text { Beaufort } \\
\text { scale }\end{array}$ & $\begin{array}{l}\text { Range } \\
\text { of wind } \\
\text { speed, } \\
\text { m.p.h. }\end{array}$ & $\begin{array}{l}\text { Mean no. of } \\
\text { air changes } \\
\text { per hr. }\end{array}$ & $\begin{array}{l}\text { Mean } \\
\text { outside } \\
\text { wind speed, } \\
\text { m.p.h. } \\
\text { A }\end{array}$ & $\begin{array}{l}\text { Mean no. of } \\
\text { air changes } \\
\text { per hr. }\end{array}$ & $\begin{array}{c}\text { Mean } \\
\text { outside } \\
\text { wind speed, } \\
\text { m.p.h. }\end{array}$ \\
\hline $\begin{array}{l}0 \\
1 \\
2\end{array}$ & $\begin{array}{l}\text { Under } 1 \\
1-3 \cdot 99 \\
4-6 \cdot 99\end{array}$ & $\begin{array}{rr}1 \cdot 05 & (2)=100 \\
1 \cdot 05 \quad(13) & =100 \\
1.64 & (4)=156\end{array}$ & $\begin{array}{l}0 \cdot 79 \\
2 \cdot 13 \\
5 \cdot 85\end{array}$ & $\begin{array}{l}0.92 \quad(2)=100 \\
0 \cdot 78 \quad(11)=85 \\
1.01 \quad(3)=110\end{array}$ & $\begin{array}{l}0 \cdot 79 \\
2 \cdot 13 \\
6 \cdot 13\end{array}$ \\
\hline \multicolumn{6}{|c|}{ Block B } \\
\hline $\begin{array}{l}0 \\
1\end{array}$ & $\begin{array}{l}\text { Under } 1 \\
1-3 \cdot 99\end{array}$ & $\begin{array}{l}1 \cdot 67 \quad(4)=100 \\
2 \cdot 14 \quad(19)=128\end{array}$ & $\begin{array}{l}0 \cdot 86 \\
2 \cdot 47\end{array}$ & $\begin{array}{l}0.79(4)=100 \\
0 \cdot 73(16)=92\end{array}$ & $\begin{array}{l}0 \cdot 86 \\
2 \cdot 35\end{array}$ \\
\hline
\end{tabular}

(b) Wind direction.

Wellner (1932) observed rates of air change which showed that wind speed had its greatest effect when the direction was directly on the external wall. It was less with a "side" wind and least of all when the direction was from the leeward. But in all the cases quoted by him a higher air change was accompanied by a higher outside wind speed, whatever its direction.

In the present observations, both in the blocks of flats $A$ and $B$, and the three houses C, D and E, little effect of wind direction on air change can be traced. As stated before, the outside wind speed was always estimated outside the external wall (or walls) of the room under test and thus some allowance is made for wind direction.

(c) Infiltration into buildings.

Apart from the entry of air into a room by means of cracks and joints in the structure, a certain amount of ventilation will take place through the boundary surfaces of the room (the walls, floor and ceiling). This infiltration 
will depend on several factors such as the type of building material used, the quality of the workmanship in the construction, and the finishing of the inner surfaces.

In fitting casement windows and doors sufficient clearance is given to permit free swinging, and the aggregate area of cracks around doors and windows, through which leakage of air can occur, is commonly considerable.

In the modern flats, block $\mathrm{A}$, there were no obvious chinks around the windows, although some were no doubt much better fitting than others, but it was noticed that in the case of the doors considerable variation in leakage area occurred. The cracks round the doors were measured and found to vary from $15 \mathrm{sq}$. in. with a well-fitting door, to $38 \mathrm{sq}$. in. with a poorer fitting one. Grouping the rooms according to the quality of fit of doors we get the results in Table 11. Both comparisons are based on rooms of similar size and construction.

Table 11. Variation in rates of air change due to quality of fit of the doors

\begin{tabular}{|c|c|c|c|c|c|}
\hline \multirow[b]{2}{*}{$\begin{array}{c}\text { Room } \\
\text { no. }\end{array}$} & \multirow[b]{2}{*}{$\begin{array}{l}\text { Area of } \\
\text { leakage } \\
\text { round } \\
\text { door, } \\
\text { sq. in. }\end{array}$} & \multicolumn{2}{|c|}{ Air grating open } & \multicolumn{2}{|c|}{ Air grating closed } \\
\hline & & $\begin{array}{l}\text { Mean no. } \\
\text { of air } \\
\text { changes } \\
\text { per hr. }\end{array}$ & $\begin{array}{c}\text { Mean } \\
\text { outside } \\
\text { wind speed, } \\
\text { m.p.h. }\end{array}$ & $\begin{array}{l}\text { Mean no. } \\
\text { of air } \\
\text { changes } \\
\text { per hr. }\end{array}$ & $\begin{array}{c}\text { Mean } \\
\text { outside } \\
\text { wind speed, } \\
\text { m.p.h. }\end{array}$ \\
\hline \multicolumn{6}{|c|}{ Modern flats: flueless rooms } \\
\hline 2 and 3 & $\begin{array}{l}27 \\
15\end{array}$ & $\begin{array}{ll}0.84 & (8) \\
0.58 & (3)\end{array}$ & $\begin{array}{l}1.69 \\
2 \cdot 35\end{array}$ & $\begin{array}{l}0.57 \text { (8) } \\
0.57\end{array}$ & $\begin{array}{l}1.69 \\
1.85\end{array}$ \\
\hline \multicolumn{6}{|c|}{ Modern flats: rooms with flues } \\
\hline & & \multicolumn{2}{|c|}{ Flue open } & \multicolumn{2}{|c|}{ Flue closed } \\
\hline $\begin{array}{l}6 \text { and } 7 \\
8 \text { and } 9\end{array}$ & $\begin{array}{l}33 \\
19\end{array}$ & $\begin{array}{l}1.35 \quad(10) \\
0.98 \quad(9)\end{array}$ & $\begin{array}{l}2 \cdot 85 \\
2 \cdot 69\end{array}$ & $\begin{array}{ll}0.85 & (9) \\
0.82 & (7)\end{array}$ & $\begin{array}{l}2 \cdot 97 \\
2 \cdot 38\end{array}$ \\
\hline
\end{tabular}

For ventilation to take place easily there must be outlets and inlets. Thus when the air gratings or flues were closed there was little variation in rate of air change with the quality of fit of the doors. But with the ventilators open the amount of leakage around the doors appeared to have a definite effect on air change.

Emswiler \& Randall (1928) produced some interesting results on the leakage through cracks in steel window frames. The steel window to be tested was built into a wind tunnel and subjected to a series of pressure differences corresponding to wind velocities up to $25 \mathrm{~m}$.p.h. With a wind speed of $5 \mathrm{~m}$.p.h. the leakage per hour per foot run of orifice was $12 \mathrm{cu}$. ft. with an opening of $\frac{1}{64} \mathrm{in}$. Cracks of $\frac{1}{32}$ and $\frac{1}{16} \mathrm{in}$. gave leakages of 20 and $40 \mathrm{cu}$. ft. per foot run per hour respectively. As in the average room the leakage openings round the windows may be many feet in length, the quantity of air that will enter the room may be considerable. Rusk, Cherry \& Boelter (1932), working also on steel-framed windows, studied the effect of $(a)$ closing the window by the action of the handle only, and $(b)$ closing the window by the handle and tightening 
the locking screw. Over a range of wind speeds the effect of using the locking screw was to reduce the infiltration by about $17 \%$.

In the present investigation the modern flats, block $\mathbf{A}$, and building $\mathbf{F}$, were both fitted with steel-framed windows, and tests were made on the effect of opening these slightly. In all cases side-hung casements were fixed by the notches on the handles, this giving opening widths from $\frac{1}{4}$ to $\frac{3}{8}$ in. Table 12 shows the results of individual experiments.

Table 12. Influence of small window openings on the rate of air change

\begin{tabular}{|c|c|c|c|c|}
\hline $\begin{array}{c}\text { Room } \\
\text { no. }\end{array}$ & Conditions of ventilation & $\begin{array}{l}\text { of air } \\
\text { changes } \\
\text { per hr. }\end{array}$ & $\begin{array}{l}\text { wind } \\
\text { speed, } \\
\text { m.p.h. }\end{array}$ & $\begin{array}{l}\text { due to } \\
\text { opening of } \\
\text { windows }\end{array}$ \\
\hline \multicolumn{5}{|c|}{ Block A (modern flats) } \\
\hline \multirow[t]{2}{*}{2} & Air grating open & 0.62 & $1 \cdot 19$ & - \\
\hline & Air grating open plus 1 casement open to $\frac{3}{8}$ in. & 0.94 & $1 \cdot 19$ & 52 \\
\hline \multirow[t]{2}{*}{3} & Air grating open & $1 \cdot 73$ & $1 \cdot 98$ & - \\
\hline & Air grating open plus 1 casement open to $\frac{1}{4}$ in. & $\mathbf{2 \cdot 6 4}$ & 1.98 & 52 \\
\hline \multirow[t]{2}{*}{4} & Air grating open & 0.56 & 0.50 & - \\
\hline & Air grating open plus 2 casements open to $\frac{3}{8}$ in. & 1.73 & 0.50 & 209 \\
\hline \multirow[t]{2}{*}{8} & Flue open & $0 \cdot 89$ & $2 \cdot 53$ & - \\
\hline & Flue open plus 2 casements open to $\frac{1}{4}$ in. & $2 \cdot 08$ & $2 \cdot 53$ & 134 \\
\hline \multirow{3}{*}{28} & Building F & & & \\
\hline & Windows and door closed & $0 \cdot 13$ & - & 一 \\
\hline & 4 casements only open to $\frac{1}{4}$ in. & $1 \cdot 35$ & - & 938 \\
\hline \multirow[t]{2}{*}{29} & Windows and door closed & 0.35 & - & - \\
\hline & 2 casements open to $\frac{1}{4}$ in. & 1.55 & - & 343 \\
\hline
\end{tabular}

The effect on the natural ventilation of a small amount of window opening is in some cases very considerable, but, bearing in mind what has been said regarding the amount of leakage which takes place through narrow cracks, the results are perhaps not surprising. Masterman et al. (1935) also found that the slight opening of a metal window frame (to a $\frac{1}{4}$ in. gap) increased the air change by one-half. This agrees with the first two experiments given in Table 12. In another room two experiments were made on the leakage around the steel-framed windows. With these normally closed draughts of incoming air could be felt at times and a fume test confirmed this. The ventilation was measured $(a)$ with the windows and door normally closed, and $(b)$ with all cracks round the windows and door sealed with glued paper strip. The rates of air change were $(a) 0.36$ and $(b) 0.078$ per hour.

It is to be expected that double windows will reduce leakage, and Wellner (1932) gives examples of their effect. A room in building $\mathrm{F}$ was provided with double steel-framed windows and two tests were made on the same day with (a) the inner windows closed, and (b) with them opened. The comparative rates of air change were:

With double windows closed $\quad \ldots \quad 0.51$ per hour

With inner windows opened $\quad \ldots \quad 0.79$ per hour

Many workers have dealt with other factors concerned in the infiltration of air through the fabrics of buildings. Houghten \& Ingels (1927) found that 
so far as infiltration was concerned a 13 in. brick wall was scarcely different from an $8 \frac{1}{2}$ in. wall, but plastering the two walls with a hard gypsum plaster rendered them practically airtight. Houghten, Gutberlet \& Herbert (1930) confirmed these results.

Wolpert (1905) showed the effect of papering a standard room and his results were:

$\begin{array}{ccc}\text { Mean no. of air changes per hr. } & \begin{array}{c}\text { Percentage excess } \\ \text { of distempered } \\ \text { over papered }\end{array} \\ 0.688 & \text { Distempered } & +20 \cdot 6 \\ 0.632 & 0.830 & +15 \cdot 2 \\ 0.626 & 0.728 & +12.9 \\ 0.528 & 0.707 & +25 \cdot 2 \\ 0.462 & 0.662 & +12.9 \\ & 0.521 & \text { Mean excess }=17.0\end{array}$

With the walls distempered the average ventilation was about $17 \%$ greater than when they were papered. Because of this Wolpert stressed the desirability of distempering bedrooms in order to get better ventilation.

Wellner (1932) showed the influence on natural ventilation of oil-painted walls. Of two rooms on the same floor the ventilation in one with the walls and ceiling oil-painted was barely half that in one in which only the lower half of the walls was painted.

In the present observations one room only (house $\mathrm{C}$ ) had painted walls, whilst the ceiling was papered. In that room the mean air change for three experiments, with the flue closed, was 0.49 per hour, a lower value than was found in other similar rooms (with distempered walls) in houses C, D and E.

Larson, Braatz \& Nelson (1929) observed the rates of air infiltration through five 13 in. brick walls each of a different grade of workmanship. The leakage through hard bricks in cement-lime mortar was only one-quarter of that through porous bricks set in lime.

\section{(d) Size of room.}

Reference has already been made to the effect of room size on the rate of air change. Other things being equal, the rate of ventilation in a room must depend on the extent of surface-walls, floor and ceiling-through which the air can pass. As in rooms of similar form the surfaces increase as the square, and the capacities as the cube, of any corresponding diameter, the proportion of surface to capacity must continually diminish with increase in size of the room. The surface area will be proportional to the two-thirds power of the volume.

Haldane (1899) worked on this basis, with the following results. He found that in one of his experimental rooms, of $1124 \mathrm{cu}$. $\mathrm{ft}$. capacity, the lowest rate of air change was once in $2 \cdot 3 \mathrm{hr}$. From this he estimated that in two other rooms, of 1390 and $5838 \mathrm{cu}$. ft. respectively, the rates of air change should be once in $2.5 \mathrm{hr}$. and once in $3.9 \mathrm{hr}$ and that the ratio of volume of 
ventilation per hour to (room volume) ${ }^{\frac{2}{3}}$ was $4 \cdot 35$. The actual results corresponded closely to these calculations. Haldane therefore assumed that, except under very exceptional circumstances, the air of a closed room of $1000 \mathrm{cu}$. ft. capacity would be changed at least once in $2.3 \mathrm{hr}$. From this basis he calculated the rates of air change likely to take place in rooms of various sizes. Haldane's results in two other rooms, of 1390 and $5838 \mathrm{cu}$. ft. capacity respectively, gave rates of air change of 0.40 and $0 \cdot 256$. The ratios for these data are $4 \cdot 46$ and 4.61. Other workers, including Masterman et al. (1935), Süpfle (1936), Wellner (1932), Wolpert $(1899,1905)$, have quoted air change determinations showing the effect of room size on natural ventilation.

The effect on the rate of ventilation of chinks and cracks in the structure has already been pointed out, and in two rooms of similar size and construction it is possible to get quite different rates of air change, the variation being due entirely to the presence of cracks not readily detectable to the eye. In Haldane's experiments his basic room and the one of $5838 \mathrm{cu}$. ft. capacity were both in a university block, with outside walls of sandstone and the others either of brick or wood and plaster. The room of $1390 \mathrm{cu}$. ft. capacity was in a private house, with one outside wall of brick and with the walls and ceiling papered. There was a fireplace, but the flue was sealed off for the experiments.

Determinations on the influence of room size on air change were made in four rooms in building $F$, and in order that the effect of chance ventilation through cracks and joints should be minimized, all the chinks round the windows and doors were sealed with strips of glued paper. Experimental details are given in Table 13.

Table 13. Ventilation ratios for four rooms in building $F$

\begin{tabular}{|c|c|c|c|c|c|}
\hline $\begin{array}{l}\text { Room } \\
\text { no. }\end{array}$ & $\begin{array}{c}\text { Cubic } \\
\text { capacity } \\
\text { of room, } \\
\text { cu. ft }\end{array}$ & (Vol.) $)_{\frac{2}{3}}$ & $\begin{array}{c}\text { Mean no. } \\
\text { of air } \\
\text { changes } \\
\text { per hr. }\end{array}$ & $\begin{array}{l}\text { Vol. of } \\
\text { air entering } \\
\text { room per hr. } \\
\text { in cu. ft. }\end{array}$ & $\frac{\text { Vol. of ventilation }}{\text { (room vol.) }}$ \\
\hline 30 & 207 & 35 & $\begin{array}{l}0.215 \\
0.229\end{array}$ & $\begin{array}{l}44 \cdot 5 \\
47 \cdot 4\end{array}$ & $\begin{array}{l}1 \cdot 27 \\
1 \cdot 35\end{array}$ \\
\hline 29 & 1089 & 105.9 & $\begin{array}{l}0.20 \\
0 \cdot 15 \\
0 \cdot 15\end{array}$ & $\begin{array}{l}218 \\
163 \\
163\end{array}$ & $\begin{array}{l}2.06 \\
1.54 \\
1.54\end{array}$ \\
\hline 31 & 1850 & $150 \cdot 8$ & $\begin{array}{l}0 \cdot 13 \\
0 \cdot 15 \\
0 \cdot 096\end{array}$ & $\begin{array}{l}241 \\
278 \\
178\end{array}$ & $\begin{array}{l}1 \cdot 60 \\
1.80 \\
1 \cdot 18\end{array}$ \\
\hline 26 & 4940 & $290 \cdot 0$ & $\begin{array}{l}0.078 \\
0.079\end{array}$ & $\begin{array}{l}385 \\
390\end{array}$ & $\begin{array}{l}1.33 \\
1.35\end{array}$ \\
\hline
\end{tabular}

A relatively small variation in the rate of air change causes much variation in the ratio given in the last column of Table 13, but there appears to be some consistency in the figures quoted. It is evident, however, when infiltration through obvious chinks is eliminated, in modern concrete structures such as building $\mathrm{F}$, with walls painted over hard plaster and no leakage through floor boards, that one gets much less ventilation than is suggested by Haldane's surface area relation. 
Turning to the results obtained in the two blocks of flats, A and B, the ratios are as shown in Table 14.

Table 14. Ventilation ratios for two blocks of flats (modern and older)

\begin{tabular}{|c|c|c|c|c|}
\hline Flats & $\begin{array}{r}\text { Roor } \\
\text { condition }\end{array}$ & $\begin{array}{l}m \text { no. and } \\
s \text { of ventilation }\end{array}$ & $\frac{\text { Vol. of ventilation }}{(\text { room vol. })^{\frac{2}{3}}}$ & Mean ratio \\
\hline $\begin{array}{l}\text { Block A } \\
\text { (Modern) }\end{array}$ & $\begin{array}{l}1 \text { (air g } \\
2 \\
3 \\
4 \\
6 \text { (flue } \\
7 \\
8 \\
9\end{array}$ & $\begin{array}{l}\text { rating closed) } \\
\quad, \\
\text { ", } \\
\text { closed) } \\
\text { ", }\end{array}$ & $\left.\begin{array}{l}4 \cdot 78 \\
4 \cdot 50 \\
5 \cdot 47 \\
4 \cdot 63 \\
8 \cdot 52 \\
5 \cdot 90 \\
9 \cdot 75 \\
3 \cdot 67\end{array}\right\}$ & $4 \cdot 85$ \\
\hline $\begin{array}{r}\text { Block B } \\
\text { (Older) }\end{array}$ & $\begin{array}{l}10 \text { (air g } \\
12 \\
11 \text { (flue } \\
13\end{array}$ & $\begin{array}{l}\text { rrating and flue closed) } \\
\text { "losed) } \\
,\end{array}$ & $\left.\begin{array}{l}8 \cdot 11 \\
6 \cdot 94 \\
8 \cdot 74 \\
6 \cdot 19\end{array}\right\}$ & $7 \cdot 50$ \\
\hline
\end{tabular}

In the above experiments flues or air gratings were normally closed, but no attempt was made to stop up any other chinks in the fabrics. The values for ventilation/(room volume $)^{\frac{2}{3}}$ show considerable variation and only tentative conclusions are possible. The older flats gave a higher ratio than the modern flats and this would be expected in view of the different qualities of the two structures. Block A (modern flats) although built of ferro-concrete yielded much larger ratios than those given for building $\mathrm{F}$, of somewhat similar construction. But in the former the walls were finished with a lime plaster and distempered, whilst in the latter they were faced with a hard, gypsum plaster and painted.

In the three houses, $\mathrm{C}, \mathrm{D}$ and $\mathrm{E}$, there was much scatter in the ratio of ventilation to (room volume) ${ }^{\frac{2}{3}}$, but for bedrooms, with ventilators and doors and windows closed, the average value was 7.94, a figure of the order obtained in the older flats (block B).

Wellner (1932) also noted the variation in the amount of natural ventilation with different buildings and he expressed his results in terms of cubic metres of air entering through each square metre of outside wall surface. He realized that air exchange took place through all walls, but it seemed that the outside wall would have most effect. The values he found for three types of houses were:

\begin{tabular}{|c|c|c|}
\hline Wood houses & & $2.0 \mathrm{~m}^{3} / \mathrm{m} .{ }^{2} / \mathrm{hr}$. \\
\hline Brick houses $\quad \ldots$ & & $2 \cdot 8$ \\
\hline Sandstone houses & & $3 \cdot 5$ \\
\hline
\end{tabular}

Wellner pointed out that cracks and joints in the structure play a large part in natural ventilation and he obtained the surprising result that the rate of air change in steel houses was much greater (by $50 \%$ ) than in houses built of wood or of brick. The ventilation in the steel houses must have been mainly through cracks and joints, as the steel itself was impermeable. 
Earlier in this paper the variation in ventilation with size of room in the older block of flats was shown. Table 15 gives the results of observations in the three houses, C, D and E.

Table 15. Comparison of rates of air change in rooms of varying size, but of similar construction

\begin{tabular}{|c|c|c|c|c|c|c|}
\hline \multirow[b]{2}{*}{$\begin{array}{c}\text { Room } \\
\text { no. }\end{array}$} & \multirow[b]{2}{*}{$\begin{array}{l}\text { Cubic } \\
\text { capacity } \\
\text { of room, } \\
\text { cu. ft. }\end{array}$} & \multirow[b]{2}{*}{ Ventilator } & \multicolumn{2}{|c|}{ Ventilator closed } & \multicolumn{2}{|c|}{ Ventilator open } \\
\hline & & & $\begin{array}{c}\text { Mean no. of } \\
\text { air changes } \\
\text { per hr. } \\
\text { House C }\end{array}$ & $\begin{array}{c}\text { Mean } \\
\text { outside } \\
\text { wind speed, } \\
\text { m.p.h. }\end{array}$ & $\begin{array}{l}\text { Mean no. of } \\
\text { air changes } \\
\text { per hr. }\end{array}$ & $\begin{array}{c}\text { Mean } \\
\text { outside } \\
\text { wind speed, } \\
\text { m.p.h. }\end{array}$ \\
\hline $\begin{array}{l}16 \\
17\end{array}$ & $\begin{array}{r}705 \\
1105\end{array}$ & $\begin{array}{c}\text { Flue } \\
\text {, }\end{array}$ & $\begin{array}{l}1 \cdot 58(5) \\
0 \cdot 84(3)\end{array}$ & $\begin{array}{l}2 \cdot 62 \\
2 \cdot 39\end{array}$ & $\begin{array}{lr}2.76 & (13) \\
1.43 & (9)\end{array}$ & $\begin{array}{l}2 \cdot 43 \\
2 \cdot 37\end{array}$ \\
\hline $\begin{array}{l}21 \\
22\end{array}$ & $\begin{array}{l}620 \\
617\end{array}$ & Flue & $\begin{array}{l}\text { House D } \\
0 \cdot 74 \text { (4) } \\
0 \cdot 87 \text { (4) }\end{array}$ & $\begin{array}{l}2 \cdot 03 \\
1 \cdot 68\end{array}$ & $\begin{array}{ll}1.26 & (4) \\
1.99 & (4)\end{array}$ & $\begin{array}{l}2 \cdot 03 \\
1 \cdot 68\end{array}$ \\
\hline $\begin{array}{l}19 \\
20\end{array}$ & $\begin{array}{l}1160 \\
1140\end{array}$ & ", & $\begin{array}{l}0.57(4) \\
0.56 \quad(4)\end{array}$ & $\begin{array}{l}1 \cdot 30 \\
0 \cdot 88\end{array}$ & $\begin{array}{ll}1 \cdot 02 & (4) \\
1 \cdot 31 & (4)\end{array}$ & $\begin{array}{l}1 \cdot 30 \\
0 \cdot 88\end{array}$ \\
\hline $\begin{array}{l}24 \\
23\end{array}$ & $\begin{array}{l}1015 \\
1810\end{array}$ & $\begin{array}{c}\text { Flue } \\
,,\end{array}$ & $\begin{array}{l}\text { House E } \\
0.99(4) \\
0.83(4)\end{array}$ & $\begin{array}{l}2 \cdot 04 \\
2 \cdot 39\end{array}$ & $\begin{array}{ll}2 \cdot 55 & (4) \\
2 \cdot 37 & (4)\end{array}$ & $\begin{array}{l}2 \cdot 04 \\
2 \cdot 64\end{array}$ \\
\hline
\end{tabular}

In each house, pairs of rooms of similar construction-apart from sizehave been chosen and the effect of cubic content on air change is clearly shown.

In rooms 16 and 17-two rooms on the same floor of house $\mathrm{C}$-tests were made in both rooms on each of 9 days with the flues open. The results are plotted in Fig. 4 and each point represents the results for the two rooms in one day's observations.

On the different days climatic conditions varied considerably, and the rates of ventilation observed varied accordingly. In spite of these variations, however, the ratio of the rate of air change in the smaller room to that in the larger one was remarkably constant, as can be seen from the way in which the observation points lie about a straight line.

\section{(e) Temperature difference between outside and inside.}

The evidence regarding the effect on air change of the difference in temperature between the room air and the outside air is very conflicting. Pettenkofer (1858) made observations in a room of $3000 \mathrm{cu}$. $\mathrm{ft}$. capacity and he found, in four experiments, that the time required for one air change varied from 1 to $3.4 \mathrm{hr}$. With the greatest air change there was a temperature difference of $38^{\circ} \mathrm{F}$. between inside air and outside air, and with the least air change a difference of only $7^{\circ} \mathrm{F}$. Pettenkofer therefore laid great stress on temperature difference as a cause of air exchange and further experiments, with only a small temperature difference, appeared to support this. He showed that under this condition the exchange of air was chiefly through the walls, and was diminished by only $28 \%$ when all the chinks and cracks were carefully 


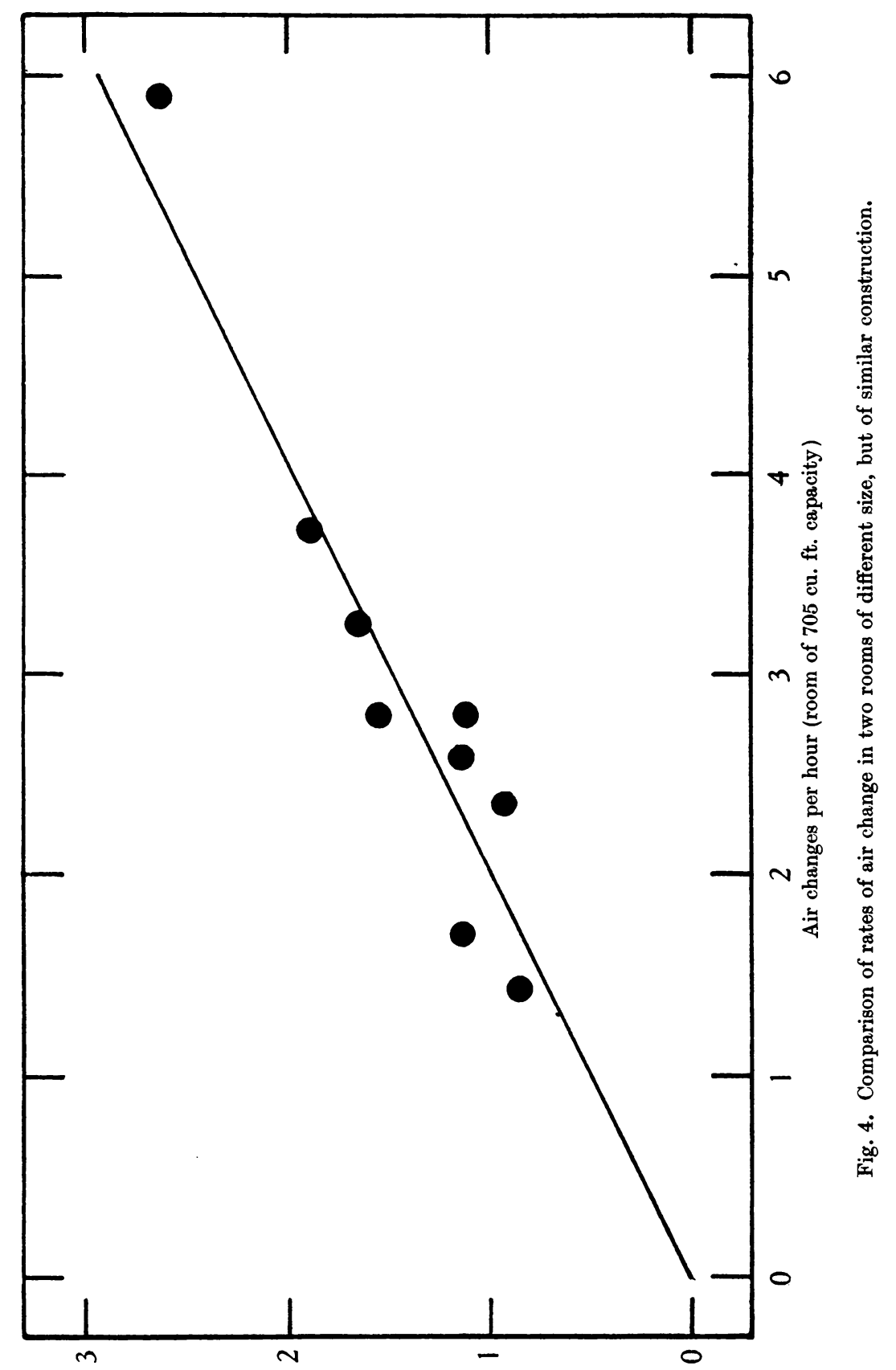

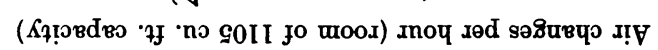


stopped up. Again, when $8 \mathrm{sq}$. ft. of window space was opened the ventilation was only doubled. In discussing these results Pettenkofer made no reference to outside wind speed and it seems likely that variations in this factor alone may have masked the presumed effect of temperature difference. Experience gained in the present investigation suggests that as the air change was only doubled when $8 \mathrm{sq}$. $\mathrm{ft}$. of window space was opened, the outside wind speed must have been extremely low, and that the day on which a small temperature difference was associated with the lowest observed air change was also calm.

Other investigators (Haldane, 1899; Wolpert, 1899, 1905; Flügge, 1922; Emswiler \& Randall, 1928; Ilzhöfer, 1930; Wellner, 1932; Süpfle, 1936) have found no appreciable effects on air change through temperature difference. The presence of a flue, however, even without a fire at its base, would be expected to affect the air change if the temperature difference is substantial. In a series of experiments at the Building Research Station (1938) to test the respective effects on air change of a wall ventilator and a flue it was found that when the average temperature difference was increased to $9^{\circ} \mathrm{F}$. the power of the flue was increased but the ventilator remained unaffected.

In the present inquiry, paying due regard to outside wind speed, careful scrutiny of the results of experiments in the flats and in the other houses has failed to reveal any effect of temperature difference on the rate of air change, even when flues were opened. But the experiments were made in unheated rooms and thus the temperature difference rarely exceeded $10^{\circ} \mathrm{F}$. and in the majority of cases it was considerably less than this figure.

\section{(f) Humidity.}

Wellner (1932) found that in some cases an increase in the absolute humidity of the air caused a diminution in air change, and he attributed this to the fact that moist air blocked the pores of the enclosing walls and rendered them less permeable. But in many modern structures walls are surfaced with hard, gypsum plaster which is then painted. Under these conditions it appears likely that any effect of humidity on permeability will be considerably reduced. An attempt has been made ìn the present observations to trace the effect of humidity on natural ventilation, but without success.

\section{Hygienic SIgNificANCE OF AIR CHANGE}

(1) Air supply

The fixing of a standard of air supply is a matter of much difficulty. Roscoe (1857) said that at least $20 \mathrm{cu}$. ft. per minute per person was necessary to remove completely the organic putrescent matter in the case of soldiers' sleeping rooms. De Chaumont (1875) advocated $50 \mathrm{cu}$. ft. per minute and that figure has been widely quoted and accepted. Such a standard is a high one and in practice it has not been maintained. For example, the London County Council requires fresh air to be supplied to cinemas and theatres at the rate of $1000 \mathrm{cu}$. ft. per person per hour, or $17 \mathrm{cu}$. ft. per minute. 
The question of air supply on a body odour basis has been followed up recently by Yaglou, Riley \& Coggins (1936), who evolved minimum fresh air requirements for various conditions of occupancy. From these results it seems reasonable to conclude that whilst for most ordinary conditions an air supply of 17-20 cu. ft. per person per minute, or 1000-1200 cu. ft. per hour, will give very satisfactory results, this standard can be somewhat reduced for enclosures where there is no danger of overcrowding. Thus in the usual occupied dwellingroom $600 \mathrm{cu}$. ft. per person per hour should produce a sufficient ventilation, but this figure must be considered as the minimum if unpleasant odours are to be avoided.

\section{(2) Present observations}

The values of air change observed in the present investigation have, in the foregoing tables, also been expressed as volumes of air entering the apartments. Considering the ventilation of bedrooms only, the following results were obtained.

Table 16. Volumes of air entering bedrooms in various dwellings

\begin{tabular}{|c|c|c|c|c|c|}
\hline \multirow[b]{2}{*}{ Room no. } & \multirow[b]{2}{*}{$\begin{array}{l}\text { Type of } \\
\text { ventilator }\end{array}$} & \multirow{2}{*}{$\begin{array}{c}\text { Average } \\
\text { floor } \\
\text { area } \\
\text { of rooms, } \\
\text { sq. ft. }\end{array}$} & \multirow{2}{*}{$\begin{array}{c}\text { Average } \\
\text { cubic } \\
\text { content } \\
\text { of rooms, } \\
\text { cu. ft. }\end{array}$} & \multicolumn{2}{|c|}{$\begin{array}{l}\text { Vol. of air entering } \\
\text { room, cu. ft. per hr. }\end{array}$} \\
\hline & & & & $\begin{array}{c}\text { Ventilator } \\
\text { open }\end{array}$ & $\underbrace{}_{\begin{array}{c}\text { Ventilato } \\
\text { closed }\end{array}}$ \\
\hline
\end{tabular}

\begin{tabular}{|c|c|c|c|c|c|}
\hline \multicolumn{6}{|c|}{ Flueless rooms } \\
\hline $\begin{array}{c}\text { Block A (modern flats) } \\
\qquad, 2,3,4\end{array}$ & $\begin{array}{l}\text { Air grating } \\
(10.5 \text { sq. in. })\end{array}$ & 86 & 670 & 580 & 386 \\
\hline $\begin{array}{c}\text { Block B (older flats) } \\
10 \text { and } 12\end{array}$ & $\begin{array}{l}\text { Air grating } \\
\text { ( } 6 \text { sq. in.) }\end{array}$ & 146 & 1165 & 1208 & 829 \\
\hline \multicolumn{6}{|c|}{ Rooms with flues } \\
\hline $\begin{array}{c}6,7,8,9 \\
6,7 \text { (I) }\end{array}$ & $\begin{array}{c}\text { Flue } \\
\text { (12.6 sq. in.) }\end{array}$ & 126 & 910 & 1078 & 767 \\
\hline $\begin{array}{c}\text { Block B (older flats) } \\
10,11,12,13\end{array}$ & $\begin{array}{l}\text { Flue } \\
\text { (53 sq. in.) }\end{array}$ & 148 & 1175 & 2300 & 820 \\
\hline $\begin{array}{l}\text { Houses C, D and E } \\
\begin{array}{c}16,17,19,20,21,22, \\
23,24\end{array}\end{array}$ & $\begin{array}{l}\text { Flue } \\
\text { (62 sq. in.) }\end{array}$ & 123 & 1020 & 1885 & 844 \\
\hline
\end{tabular}

In the modern flats the volumes of air entering the flueless rooms were not large. With $(a)$ the air gratings open, and $(b)$ the air gratings closed, the ventilation per hour amounted to only 580 and $386 \mathrm{cu}$. ft. respectively. The rooms provided with gas-fire flues had 1078 or $767 \mathrm{cu}$. ft. of air exchange per hour according to whether the flues were opened or closed.

Rooms in the older flats and the three houses had about $800 \mathrm{cu}$. ft. of air entering per hour when the fixed form of ventilator was blocked up. Opening an air grating increased the air flow in two of these rooms to $1208 \mathrm{cu}$. ft. per hour, whilst in twelve apartments the action of a flue resulted in 1885-2300 cu. ft. of ventilation per hour. 
Rooms 1-4 in the modern flats were intended to be used as single bedrooms, but it is seen from Table 16 that the amount of air available with the grating open was barely adequate, judged even on the suggested lowest standard of $600 \mathrm{cu}$. ft. per person per hour and that when the ventilator was closed the air supply was only two-thirds of this value. All the other apartments listed in Table 16 were double bedrooms and working on the assumption that there would normally be two occupants in these rooms we see that in the older flats, block B, the air grating when open gave $600 \mathrm{cu}$. ft. per head per hour, but when the grating was closed the ventilation again was only two-thirds of the desirable minimum.

In the rooms provided with ordinary fireplace flues (block B and houses $\mathrm{C}, \mathrm{D}$ and $\mathrm{E}$ ), the ventilation when the flues were open was considerable and adequate. The rooms with gas-fire flues in the modern flats had only a 4 in. diameter pipe as the means of ventilation, but whilst this small flue when open did cause some increase in the rate of air change, the ventilation was still hardly sufficient.

In all the rooms with flues, both in the modern and older buildings, the closure of these ventilators gave ventilation rates much below the $600 \mathrm{cu}$. $\mathrm{ft}$. per person per hour standard.

An air grating, by virtue of its usual position above head level can, under appropriate outside conditions, namely a cold and direct wind, produce a draught. The grating, therefore, becomes a nuisance and it is often put out of action by being blocked up. A flue of adequate size, on the other hand, does not produce any objectionable draught, but it does act as a good ventilator.

In 1936, an Advisory Committee appointed by the Royal College of Physicians to inquire into the "Domestic heating by Gas considered from the point of view of Health and Comfort" commented on the small amount of precise information available on the subject of air change. It has usually been assumed that, in ordinary flueless rooms without an air grating, and with doors and windows shut, at least 0.5 of an air change per hour is obtained. With reliable evidence on the subject limited, the Committee was inclined to believe that this figure was an under-estimate, and that at least in small rooms not exceeding $1000 \mathrm{cu}$. ft. capacity the air change would rarely be below 1 per hour. It also said "it is open to doubt whether in small occupied rooms an air change of 1 per hour or less may be regarded as satisfactory on grounds of health and comfort". Thus in a room of $600 \mathrm{cu}$. ft. capacity at least one change per hour would be required to ensure the $10 \mathrm{cu}$. ft. per minute for one occupant, judged to be the minimum requirement necessary if objectionable body odours are to be avoided. This applies to a room whether heated by gas, or electricity, or any other means, but it is more important if the source of heat is a gas appliance not connected with a flue.

On the subject of heating by flueless gas appliances the Committee pointed out that a room of $500 \mathrm{cu}$. ft. capacity could be adequately warmed in cold weather by a flueless gas heater burning continuously and consuming $5 \mathrm{cu}$. $\mathrm{ft}$. 
of gas per hour. Assuming the gas to have a 20 grain sulphur content it was found that about 1.67 air changes per hour would be necessary to keep the sulphur oxides within the permissible limit of concentration of $0.0001 \%$, this allowing for a $50 \%$ absorption of these harmful products by the walls and furnishings.

Percentage frequency distributions for the rates of air change observed in the two blocks of flats are given in Table 17.

\section{Table 17. Percentage frequency distributions for rates of} air change observed in two blocks of flats

\begin{tabular}{|c|c|c|c|c|c|c|c|}
\hline \multirow{5}{*}{$\begin{array}{l}\text { Range of } \\
\text { air change } \\
\text { observed }\end{array}$} & \multicolumn{4}{|c|}{ Block A (modern flats) } & & & \\
\hline & \multirow{2}{*}{\multicolumn{2}{|c|}{$\begin{array}{l}\text { Rooms with } \\
\text { air grating: } \\
\text { mean cubic content } \\
670 \mathrm{cu} . \mathrm{ft} .\end{array}$}} & \multirow{3}{*}{\multicolumn{2}{|c|}{$\begin{array}{c}\text { Rooms with flue: } \\
\text { mean cubic content } \\
910 \text { cu. } \mathrm{ft} .\end{array}$}} & \multicolumn{3}{|c|}{ Block B (older flats) } \\
\hline & & & & & \multicolumn{3}{|c|}{$\begin{array}{l}\text { Mean cubic content of rooms, } \\
\qquad 1170 \mathrm{cu} . \mathrm{ft} .\end{array}$} \\
\hline & \multirow{2}{*}{$\begin{array}{c}\text { Air } \\
\text { grating } \\
\text { open }\end{array}$} & \multirow{2}{*}{$\underset{\text { grating }}{\text { Air }}$} & & & \multirow[b]{2}{*}{$\begin{array}{l}\text { Ventilator } \\
\text { closed }\end{array}$} & \multirow{2}{*}{$\underset{\substack{\text { Air } \\
\text { open }}}{ }$} & \multirow[b]{2}{*}{$\begin{array}{l}\text { Flue } \\
\text { open }\end{array}$} \\
\hline & & & $\begin{array}{l}\text { Flue } \\
\text { open }\end{array}$ & $\begin{array}{l}\text { Flue } \\
\text { closed }\end{array}$ & & & \\
\hline $0 \cdot 30-0 \cdot 39$ & - & 18 & - & 12 & - & - & - \\
\hline $0 \cdot 40-0 \cdot 49$ & 5 & 18 & 5 & - & 29 & - & - \\
\hline $0.50-0.74$ & 50 & 53 & 5 & 38 & 33 & 30 & 4 \\
\hline $0.75-0.99$ & 22 & 11 & 32 & 6 & 25 & 10 & - \\
\hline $1 \cdot 00-1 \cdot 49$ & 18 & - & 42 & 38 & 13 & 50 & 22 \\
\hline $1 \cdot 50-1.99$ & 5 & - & 11 & 6 & - & 10 & 13 \\
\hline $2 \cdot 00-2 \cdot 49$ & - & - & - & - & - & - & 39 \\
\hline $2 \cdot 50-2.99$ & - & - & - & - & - & - & 18 \\
\hline 3 and over & - & - & 5 & - & 一 & - & 4 \\
\hline \multirow{2}{*}{$\begin{array}{l}\text { Mean air change } \\
\text { observed }\end{array}$} & & & & & & & \\
\hline & $0 \cdot 83$ & 0.55 & $1 \cdot 17$ & $0 \cdot 84$ & 0.71 & $1 \cdot 04$ & $2 \cdot 06$ \\
\hline No. of exps. & 22 & 17 & 19 & 16 & 24 & 10 & 23 \\
\hline
\end{tabular}

Note: The rates of air change for closed conditions in Block $A$ are contrary to what has been said regarding the effect of room size on ventilation: i.e. the smaller rooms have a lower air change. The larger rooms, however, had a much greater opening window area and the air leakage through the cracks of these opening sections probably accounted for the inversion of the accepted effect of room size.

Reference to Table 17 shows that in flueless rooms (of $670 \mathrm{cu}$. ft. average capacity) with air gratings closed, $36 \%$ of the observations gave an air change of less than $0 \cdot 5,89 \%$ came below $0 \cdot 75$, and on no occasion did the natural ventilation exceed 1 air change per hour. In the Building Research Station Note (D.S.I.R. 1938) it was observed that in a heated flueless room, with an ordinary wall ventilator, the air change may fall as low as 0.3 per hour, or even less. These findings indicate that in small flueless rooms, with ventilators closed, the ventilation is generally much less than could be desired, and it is suggested that the question of the use of flueless gas heaters in such rooms should be reconsidered.

\section{Summary}

Measurements of the rate of ventilation were made on 312 occasions in thirty-one rooms in (a) a block of older flats, (b) a block of modern flats, $(c)$ three villa residences, and $(d)$ a modern university building. 
The rate of air change was determined by liberating a quantity of coal gas into the room and measuring the rate of its subsequent disappearance by means of a katharometer.

The effects on natural ventilation of air gratings and flues were studied in unheated rooms in two blocks of flats. The effective orifices of the gratings were 10.5 sq. in. in the modern flats and 6 sq. in. in the older ones. With the air gratings or flues (if any) closed the rates of air change were 0.55 and 0.71 per hour respectively. With the air gratings open the air change was increased to 0.83 per hour in the modern flats and to 1.04 per hour in the older ones.

The flues in the modern flats in connexion with gas fires were 4 in. diameter pipes (cross-sectional area, 12.6 sq. in.); in the older flats the ordinary fireplaces were connected to standard flues and the area of the register openings was $53 \mathrm{sq}$. in. When the flues were sealed, the air changes per hour in the modern and older flats were 0.84 and 0.72 respectively and when the flues were opened these rates of ventilation were increased to 1.17 and 2.06 air changes per hour. In nine rooms in three other houses the average ventilation rates with the flues closed and open were respectively 0.82 and 1.76 air changes per hour.

The ordinary chimney flue, even without a fire at its base, was an efficient ventilator, but the flue of smaller dimensions was far less effective.

With windows open almost any required amount of ventilation could be obtained, and the observations showed that even when windows are opened only slightly the ventilation is distinctly increased. Thus, in flueless rooms of the modern flats, with doors and windows closed, but with the air grating open, the ventilation amounted to 0.83 air changes per hour, but with one casement only open to a width of $\frac{3}{8}$ in. it was increased to 1.79 air changes.

The effects of various factors on the rate of air change are discussed and illustrated. Of these, outside wind speed appears to have most influence. The evidence regarding the effect on ventilation of the difference in temperature between the room air and the outside air is very conflicting. In the present observations, when outside wind speed is taken into account, no definite effect of temperature difference on air change is seen. But the experiments were made in unheated rooms and the temperature difference rarely exceeded $10^{\circ} \mathrm{F}$., and in the majority of cases was much less.

The various recommended standards of air supply are discussed. Although certain bye-laws require a fresh-air supply of $1000 \mathrm{cu}$. $\mathrm{ft}$. per person per hour, it is probable that where there is no overcrowding, as in the normally occupied dwelling-room, a ventilation rate of not less than $600 \mathrm{cu}$. $\mathrm{ft}$. per person per hour should be sufficient to prevent body odours from becoming apparent.

The results of this inquiry show that in closed, flueless rooms, the air supply is likely to be much below $600 \mathrm{cu}$. ft. per hour per occupant.

On account of the low ventilation rates observed in flueless rooms it is desirable that the question of the use of flueless gas heaters in such rooms be reconsidered. 
Acknowledgements. The author wishes to express his indebtedness to Dr T. Bedford, of the Industrial Health Research Board, for helpful advice and criticism.

\section{REFERENCES}

DAynes, H. A. (1920). (Introductory note by Shakespear, G. A.) The theory of the katharometer. Proc. Roy. Soc. A, 97, 273.

De Chaumont, F. S. B. F. (1875). Lectures on State Medicine. London: Smith, Elder and Co.

D.S.I.R. (1938). The ventilation of flueless rooms: Note from the Building Research Station. J. Instn Heat. Vent. Engrs, Lond., 6, 428.

Emswiler, J. E. \& RANDaLL, W. C. (1928). The weather-tightness of rolled section steel windows. J. Amer. Soc. Heat. Vent. Engrs, 34, 477.

FLÜGGE, R. (1922). Untersuchungen über Lüftungseinrichtungen in Kleinhäusen. Z. Hyg. InfektKr. 96, 426.

Haldane, J. S. (1899). Report of the Departmental Committee appointed to enquire into the Manufacture and Use of Water Gas and other Gases containing a large proportion of Carbonic Oxide, Appendix I. H.M.S.O., C. 9164.

Houghten, F. C. \& INGELS, M. (1927). Infiltration through plastered and unplastered brick walls. J. Amer. Soc. Heat. Vent. Engrs, 33, 249.

Houghten, F. C., Gutberlet, C. \& Herbert, C. A. (1930). Air leakage through various forms of building construction. Heat. Pip. Air Condit. 2, 1044.

ILZHÖFER, H. (1930). Untersuchungen über natürliche und künstliche Lüftung von Wohnräumen. Arch. Hyg. 105, 322.

Kisskalt, K. (1913). Gesundheits-Ing. 36, 853.

Larson, G. L., Braatz, C. \& Nelson, D. W. (1929). Air infiltration through various types of brick wall construction. J. Amer. Soc. Heat. Vent. Engrs, 35, 125.

Marley, W. G. (1935). The measurement of the rate of air change. J. Instn Heat. Vent. Engrs, Lond., 2, 499.

Masterman, C. A., Dunning, E. W. B. \& Densham, A. B. (1935). Report on air vitiation and gas appliances. Instn Gas Engrs, Publ. No. 116, Oct. 1935.

Pettenkofer, Max von (1858). Ueber den Luftwechsel in Wohngebäuden. Munich.

Roscos, H. E. (1857). Report to the General Board of Health by the Commissioners appointed to inquire into the Warming and Ventilation of Dwellings. Appendix, p. 127.

Royal College of Physicians of London (1936). Domestic Heating by Gas considered from the point of view of Health and Comfort. London: Harrison and Sons, Ltd.

Rusk, D. O., Cherry, V. H. \& Boelter, L. (1932). Air infiltration through steel-framed windows. Heat. Pip. Air Condit. 4, 696.

SüPFLE, K. (1936). Die Grösse der natürlichen Ventilation in Wohnräumen und die Lehre vom Luftkubus. Arch. Hyg. 117, 187.

WeLLNER, P. (1932). Untersuchungen über die Grösse des natürlichen Luftwechsels in Wohnungen äterer und neuerer Bauweise. Von der Sachsischen Technischen Hochschule zu Dresden zur Erlangung der Wurde eines Doktor-Ingenieurs genehmigte. Dissertation vorgelegt von Dipl-Ing. Paul Wellner aus Plaue bei Floha i. Sa.

Wolpert, H. (1899). Ueber die Grösse des Selbstlüftungs-Coëfficienten kleiner Wohnräume. Arch. Hyg. 36, 220.

WOLPERT, H. (1905). Über den Einfluss der landhausmässigen Bebauung auf die natürliche Ventilation der Wohnräume. Arch. Hyg. 52, 46.

Yaglou, C. P., RIIEY, E. C. \& Cogarns, D. I. (1936). Ventilation requirements. Heat. Pip. Air Condit. 9, 447. 